\title{
Progress on Southeast Asia's Flora projects
}

\author{
D.J. Middleton ${ }^{1}$, K. Armstrong 2 , Y. Baba ${ }^{3}$, H. Balslev ${ }^{4}$, K. Chayamarit ${ }^{5}$, \\ R.C.K. Chung 6 , B.J. Conn ${ }^{7}$, E.S. Fernando ${ }^{8}$, K. Fujikawa ${ }^{9}$, R. Kiew ${ }^{6}$, H.T. Luu ${ }^{10}$, \\ Mu Mu Aung ${ }^{11}$, M.F. Newman ${ }^{12}$, S. Tagane ${ }^{13}$, N. Tanaka ${ }^{14}$, D.C. Thomas ${ }^{1}$, \\ T.B. $\operatorname{Tran}^{15}$, T.M.A. Utteridge ${ }^{16}$, P.C. van Welzen ${ }^{17}$, D. Widyatmoko ${ }^{18}$, \\ T. Yahara $^{14}$ \& K.M. Wong ${ }^{1}$
}

${ }^{1}$ Singapore Botanic Gardens, National Parks Board, 1 Cluny Road, 259569 Singapore david_middleton@nparks.gov.sg

${ }^{2}$ New York Botanical Garden, 2900 Southern Boulevard, Bronx, New York, 10458, USA

${ }^{3}$ Auckland War Memorial Museum Tāmaki Paenga Hira,

Private Bag 92018, Auckland 1142, New Zealand

${ }^{4}$ Ecoinformatics and Biodiversity, Department of Bioscience, Aarhus University Building 1540, Ny Munkegade 114, Aarhus C DK 8000, Denmark

${ }^{5}$ The Forest Herbarium, National Park, Wildlife and Plant Conservation Department, 61

Phahonyothin Rd., Chatuchak, Bangkok 10900, Thailand

${ }^{6}$ Herbarium, Forest Research Institute Malaysia, Kepong, Selangor 52109, Malaysia

${ }^{7}$ School of Life and Environmental Sciences, University of Sydney, NSW 2006, Australia

${ }^{8}$ Department of Forest Biological Sciences, College of Forestry \& Natural Resources,

University of the Philippines - Los Baños, College, 4031 Laguna, Philippines

${ }^{9}$ Kochi Prefectural Makino Botanical Garden, 4200-6 Godaisan, Kochi, 7818125, Japan

${ }^{10}$ Southern Institute of Ecology, Vietnam Academy of Science and Technology, 01 Mac Dinh

Chi Street, District 1, Ho Chi Minh City, Vietnam

${ }^{11}$ Forest Research Institute, Forest Department, Ministry of Natural Resources and

Environmental Conservation, Yezin, Nay Pyi Taw, Myanmar

${ }^{12}$ Herbarium, Royal Botanic Garden Edinburgh, Edinburgh EH3 5LR, Scotland

${ }^{13}$ Kagoshima University Museum, Kagohshima University,

1-21-30 Korimoto, Kagoshima, 890-0065, Japan

${ }^{14}$ Department of Botany, National Museum of Nature and Science, Amakubo 4-1-1, Tsukuba, Ibaraki 305-0005, Japan

${ }^{15}$ Herbarium, Botany Department, Institute of Ecology and Biological Resources (IEBR), Vietnam Academy of Science and Technology (VAST), 18. Hoang Quoc Viet Street,

Nghia Do, Cau Giay, Hanoi, Vietnam

${ }^{16}$ Royal Botanic Gardens, Kew, Richmond, Surrey, TW9 3AE, UK

${ }^{17}$ Naturalis Biodiversity Center, P.O. Box 9517, 2300 RA Leiden, Netherlands

${ }^{18}$ Indonesian Institute of Sciences (LIPI), Kebun Raya Bogor, Jl. Ir. H. Juanda 13,

Bogor, Jawa Barat 16122, Indonesia

ABSTRACT. Southeast Asia (Myanmar, Thailand, Cambodia, Laos, Vietnam, Malaysia, Singapore, Brunei Darussalam, Indonesia, Timor Leste, the Philippines and Papua New Guinea) is a region of high plant diversity with an estimated 50,000 flowering plant species. Estimates of plant diversity in the region continue to grow as large numbers of new species are described even though there have been suggestions that there are few new species to be 
found in some parts of Southeast Asia. It is likely that most estimates of species numbers in the countries of Southeast Asia are too low due to the lack of taxonomic work on groups which have many locally endemic species. Differing collecting densities across the region can profoundly affect our understanding of plant diversity and lead to large underestimates of species diversity in poorly collected countries and regions. Progress on each of the major Flora projects in Southeast Asia, Flora of Thailand, the Flora of Cambodia, Laos and Vietnam/Flore $d u$ Cambodge, du Laos et du Viêtnam, Flora Malesiana, Flora of Peninsular Malaysia, Tree Flora of Sabah and Sarawak, Flora of Singapore and Flora of Vietnam, along with floristic research in Myanmar, the only country not covered by at least one of these Flora projects, is discussed. In addition to the formal Flora projects, there is much floristic activity occurring in the countries otherwise covered by transnational Floras.

Keywords. Collecting density, floristics, plant diversity

\section{Introduction}

It is estimated that there are around 50,000 flowering plant species in the countries of Southeast Asia (approximation, allowing for large overlaps, based on figures in Corlett \& Primack, 2011, Middleton, 2003b and our own calculations), these being Myanmar, Thailand, Cambodia, Laos, Vietnam, Malaysia, Singapore, Brunei Darussalam, Indonesia, Timor Leste, the Philippines and Papua New Guinea. Flowering plants constitute approximately $96 \%$ of vascular plants (Joppa et al., 2011) so the differences in focus in the literature between flowering and vascular plants for estimates in the number of species can be said to be negligible considering how very approximate these figures are. Exactly how many species there are remains very poorly known as so much of the region is underexplored and so many of the plants have yet to be studied. Estimates of the number of species worldwide have varied up and down over time (Table 1), but at least in the Malesian region (Peninsular Malaysia to Papua New Guinea), the number of species has only ever climbed upwards from 25,000 (Geesink, 1990) to 42,000 (Roos, 1997) to 45,000 (Corlett \& Primack, 2011). That we do not have a more accurate estimate of the number of species in the whole of Southeast Asia is because none of the major Flora projects in the region is yet complete.

Obtaining more accurate plant diversity data is a priority of the Global Strategy for Plant Conservation 2011-2020, Target 1 of which states 'the development of a Flora of all known plants is a fundamental requirement for plant conservation by 2020'. A wide range of users needs to be able to identify plants for many and varied reasons, especially if the conservation management of a region is to be based on wellsupported data. Floras are the most accessible tools for plant identification in an area, much more so than attempting to collate and use monographic or other taxonomic papers, even supposing they exist for many plant groups. The establishment of a Flora project in a region usually also has the effect of stimulating collecting effort, active curation of existing collections, and ensuring that the botanical infrastructure can support these activities. Completed Floras are needed but accounts are lacking for many plant groups, particularly for the largest plant families and genera. Nevertheless, 
Table 1. Estimates of number of species of vascular plants in the world

\begin{tabular}{ll}
\hline Estimated number of species & Reference \\
\hline 250,000 & Groombridge (1992) \\
320,000 & Prance et al. (2000) \\
422,127 & Govaerts (2001) \\
350,000 & Bebber et al. (2010) \\
383,671 & Nic Lughadha et al. (2016) \\
379,500 & Willis (2017) \\
\hline
\end{tabular}

taxonomic research on the plant diversity of Southeast Asian countries progresses and large numbers of new species are described each year (Fig. 1).

In this paper we will assess what is currently known of the overall levels of plant diversity in Southeast Asia, how many more species might be expected to be found, what the collection densities across the region are, and what effect this has on our understanding of plant diversity. We start with an assertion that despite whatever limitations may be highlighted, the completion of the major Flora projects in Southeast Asia is nevertheless vital to ensure we have baseline data for further research and as a practical tool to identify plants. We will, therefore, also discuss the progress of the major Flora projects in the region and assess any other additional floristic projects or potential projects in each country, with the exception of Timor Leste about which we have too little information.

\section{Species discovery}

Based on a world total of around 350,000 flowering plant species, Bebber et al. (2010) estimated that approximately $20 \%$, i.e. some 70,000 species, were yet to be described, which Joppa et al. (2011) called 'missing species'. With approximately 50,000 species, the flowering plant diversity of Southeast Asia comprises about 15\% of the world's total which, if the number of species yet to be described is evenly distributed across the world, would have meant that in 2010 there were over 10,000 undescribed species in the region. As Joppa et al. (2011) noted, the 'missing species' are not evenly distributed across the world and their estimate of the number of undescribed species in Southeast Asia was only around 1540 species (extrapolating from the figures in their Table 1). Based on the data they analysed, they estimated surprisingly low numbers of 'missing species' in Southeast Asia but it should be noted that already almost 3000 new species have been described from Southeast Asia since 2011 (Fig. 1). Despite the 


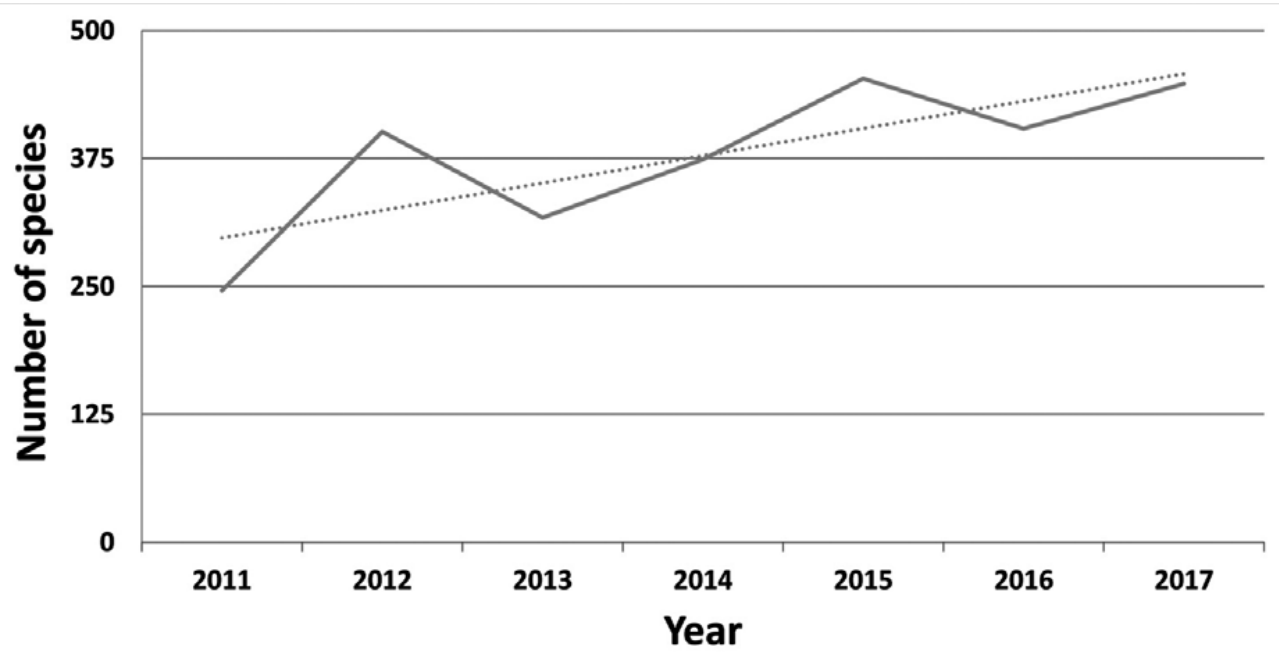

Fig. 1. New species described from Southeast Asia per year, 2011-2017 (data from the International Plant Names Index). The dotted line is the trend.

claim in Joppa et al. (2011) that "...the majority of regions provide sensible estimates of species remaining to be discovered", the prediction from their model that there are almost no new species to be discovered in the Philippines and Sumatra and extremely few in Thailand, Vietnam and New Guinea (Table 1 in Joppa et al., 2011), does not correspond to the actual numbers of new species described from 2011-2017 from each of these areas, being 417 species from the Philippines, 116 species from Sumatra, 450 species from Thailand, 530 species from Vietnam and 465 species from New Guinea (data from the International Plant Names Index). It must also be noted that many of these areas with large numbers of new species being discovered are also regions that require far more intensive basic taxonomic research with the possibility that 'known' species may need to be recircumscribed.

\section{Collections from Southeast Asia}

Species discovery and publication relies on the collecting activities of botanists and collaborators throughout the region, as well as the diligence of herbarium curatorial staff to ensure that the material is properly processed and made available to researchers. Bebber et al. (2010) suggested that $47-66 \%$ of undescribed species had already been collected and were awaiting study and description in the herbaria of the world. The figures on which these estimates are based are debatable but there is no doubt that herbaria with large holdings of Southeast Asian plants are likely to already have large numbers of undescribed species amongst their accessions. Yet even if these estimates are true, that still leaves many thousands of species that have not yet been described because they have not yet even been collected for the first time. Collection of plant specimens for the herbarium and eventual taxonomic study remains vital. 
The patterns of collection across Southeast Asia, including within countries (Conn, 1994; Parnell et al., 2003), are extremely uneven (Johns, 1995; Prance et al., 2000; Prance, 2001; Middleton, 2003b). Table 2 gives estimates of collection density for each of the countries or major islands in the Southeast Asian region. It must be emphasised that these are estimates based on very sporadic and often out-of-date data and we expect, and hope, that these figures will be a spur for the calculation of more accurate estimates in the future.

Differential collection densities can have profound effects on our understanding of the plant diversity of each region. For example, the numbers of species of Rauvolfioid and Apocynoid Apocynaceae (Table 3) and Gesneriaceae (Table 4) in Thailand can be compared with those in Cambodia, Laos and Vietnam (CLV). In Table 3, the total number of genera and species of Rauvolfioid and Apocynoid Apocynaceae (formerly two subfamilies, now treated as informal groups and corresponding to the Apocynaceae before the inclusion of the Asclepiadaceae) is broadly similar in the two regions and many species are found in both regions. Fig. 2 shows the number of specimens known per species of Rauvolfioid and Apocynoid Apocynaceae from the latest revisions of several genera. The high number of species known from 20 or more collections reflects the fact that many species are widespread and have been collected in many different regions. The lower number of species known only from few collections broadly reflects the relatively few species that are locally endemic and therefore less likely to be collected. Consequently the overlap in species between Thailand and CLV is large. An examination of widespread species in Thailand (Middleton, 1999) and China (Li et al., 1995) suggests there are only around four widespread species that should be expected in CLV but which have not yet been collected. Despite the lower collection density in CLV, and the consequent likelihood that narrowly endemic species could be overlooked, the percentage of endemic species in CLV is slightly higher than in Thailand. There are, however, seven species of Wrightia R.Br. that are locally endemic in Thailand, primarily on limestone, yet there are no locally endemic species in CLV. The climatic and habitat preferences of these Wrightia species in Thailand are available in neighbouring CLV and it is likely that undescribed species will occur there. It is also possible that additional species of genera such as Kopsia Blume and Alstonia R.Br. that do already have locally endemic species in CLV will be found. Although we are aware that it is very speculative, we suggest that there may be a further 10-15 species of Rauvolfioid and Apocynoid Apocynaceae that have not yet been collected.

In contrast, Table 4 shows that there are very many more known species of Gesneriaceae in Thailand than there are in CLV and that the overlap in both genera and species is very much smaller than for Apocynaceae. Fig. 3 shows the number of specimens known per species of Gesneriaceae from the latest revisions of a number of genera in Southeast Asia and shows a pattern that broadly reflects the large number of species that are narrowly endemic, and consequently infrequently collected, and the fewer species that are widespread. The percentage of endemic species of Gesneriaceae in Thailand is $59 \%$ but in CLV it is only $40 \%$ from a much lower basis of total number of species. If we were to speculate only that the percentage of endemic species in CLV is likely to be similar to Thailand, this would imply around 30 species were yet to be 
Table 2. Estimates of collection density in the countries or major islands of Southeast Asia.

\begin{tabular}{lll}
\hline Country or island & $\begin{array}{l}\text { Estimated number of } \\
\text { collections per } \mathbf{1 0 0} \mathbf{~ k m}^{\mathbf{2}}\end{array}$ & $\begin{array}{l}\text { Reference (* indicates our own } \\
\text { estimates) }\end{array}$ \\
\hline Borneo & 35 & Campbell \& Hammond (1989) \\
Cambodia & 16 & $*$ \\
Java & 199 & Campbell \& Hammond (1989) \\
Laos & 10 & $*$ \\
Myanmar & 20 & $*$ \\
Papua New Guinea & 46 & Campbell \& Hammond (1989) \\
Peninsular Malaysia & 200 & Middleton (2003b) \\
Philippines & 80 & $*$ \\
Singapore & 5721 & Niissalo et al. (2014) \\
Sulawesi & 24 & Campbell \& Hammond (1989) \\
Sumatra & 22 & Campbell \& Hammond (1989) \\
Thailand & 75 & $*$ \\
Vietnam & 43 & $*$ \\
\hline
\end{tabular}

Table 3. Number of genera and species of Rauvolfioid and Apocynoid Apocynaceae in Thailand, in Cambodia, Laos and Vietnam, the endemic species in each region, and the overlap in genera and species between them. Data from Middleton (1999, 2009b, 2010, 2013, 2014) and Wai et al. (2012).

\begin{tabular}{llll}
\hline Floristic region & $\begin{array}{l}\text { Number of } \\
\text { genera }\end{array}$ & $\begin{array}{l}\text { Number of } \\
\text { species }\end{array}$ & $\begin{array}{l}\text { Number of } \\
\text { endemics }\end{array}$ \\
\hline Thailand & 37 & 124 & $12(10 \%)$ \\
Cambodia, Laos \& Vietnam & 38 & 119 & $17(14 \%)$ \\
Overlap & 36 & 82 & \\
\hline
\end{tabular}


Table 4. Number of genera and species of Gesneriaceae in Thailand, in Cambodia, Laos and Vietnam, the endemic species in each region, and the overlap in genera and species between them. Data unpublished and compiled here.

\begin{tabular}{llll}
\hline Floristic region & $\begin{array}{l}\text { Number of } \\
\text { genera }\end{array}$ & $\begin{array}{l}\text { Number of } \\
\text { species }\end{array}$ & $\begin{array}{l}\text { Number of } \\
\text { endemics }\end{array}$ \\
\hline Thailand & 31 & 239 & $140(59 \%)$ \\
Cambodia, Laos \& Vietnam & 31 & 155 & $61(40 \%)$ \\
Overlap & 21 & 40 & \\
\hline
\end{tabular}

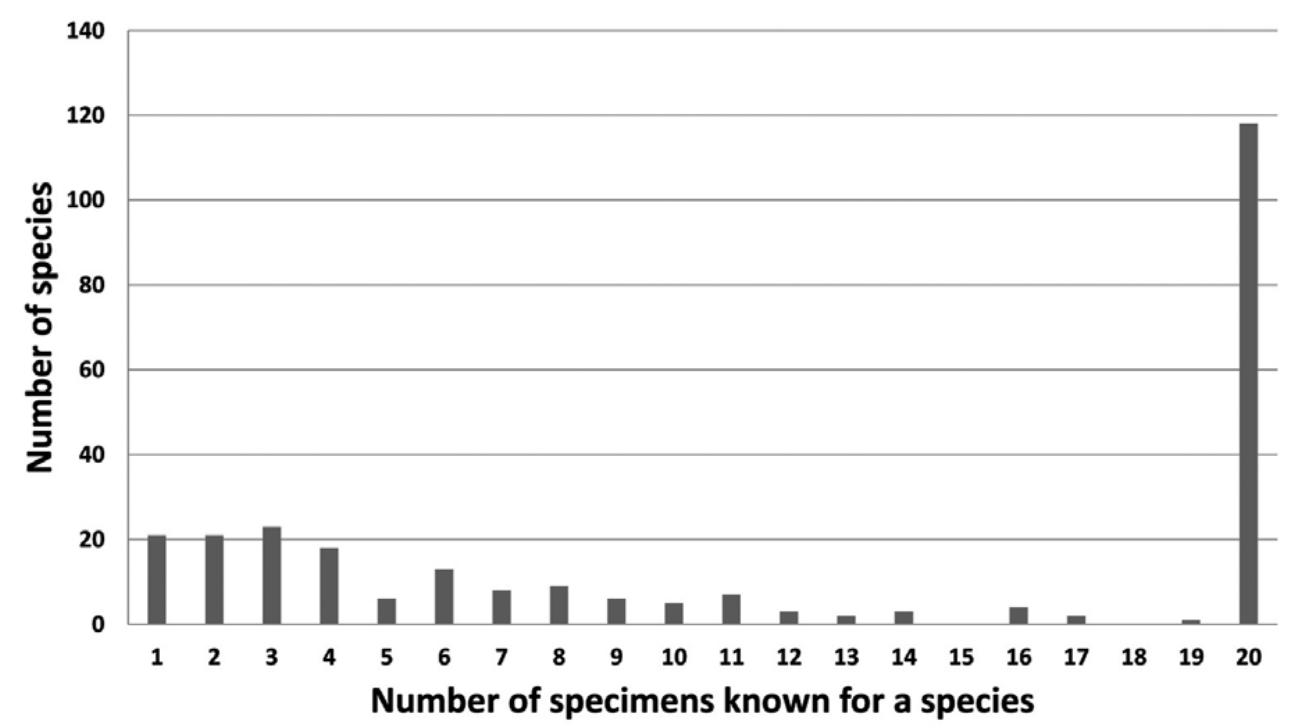

Fig. 2. Number of collections known (the 20 representing $\geq 20$ ) for each species from recent revisions of 270 species of Rauvolfioid and Apocynoid Apocynaceae. Data from Leeuwenberg (1985, 1991), Rudjiman (1987), Sidiyasa (1998), Middleton (1993, 1994, 1995a, 1995b, 1996a, 1996b, 1996c, 1997, 2000, 2003a, 2004, 2005a, 2005b) and Hendrian \& Middleton (1999). Data from revisions of taxa from only restricted geographical areas are only included if the number of specimens from outside the area is known and incorporated.

discovered in CLV. If, however, we were to reason that the total number of species in CLV is likely to be similar or slightly higher than in Thailand, as it is for the Rauvolfioid and Apocynoid Apocynaceae, there could be up to 100 species of Gesneriaceae, most of them still undiscovered and undescribed, yet to be accounted for in CLV.

Although it is not surprising that a family such as the Gesneriaceae, already known for having large numbers of locally endemic species in other parts of Southeast Asia, should be particularly poorly represented in a region of low collecting density, the contrast here between the Apocynaceae and Gesneriaceae may point to there being 


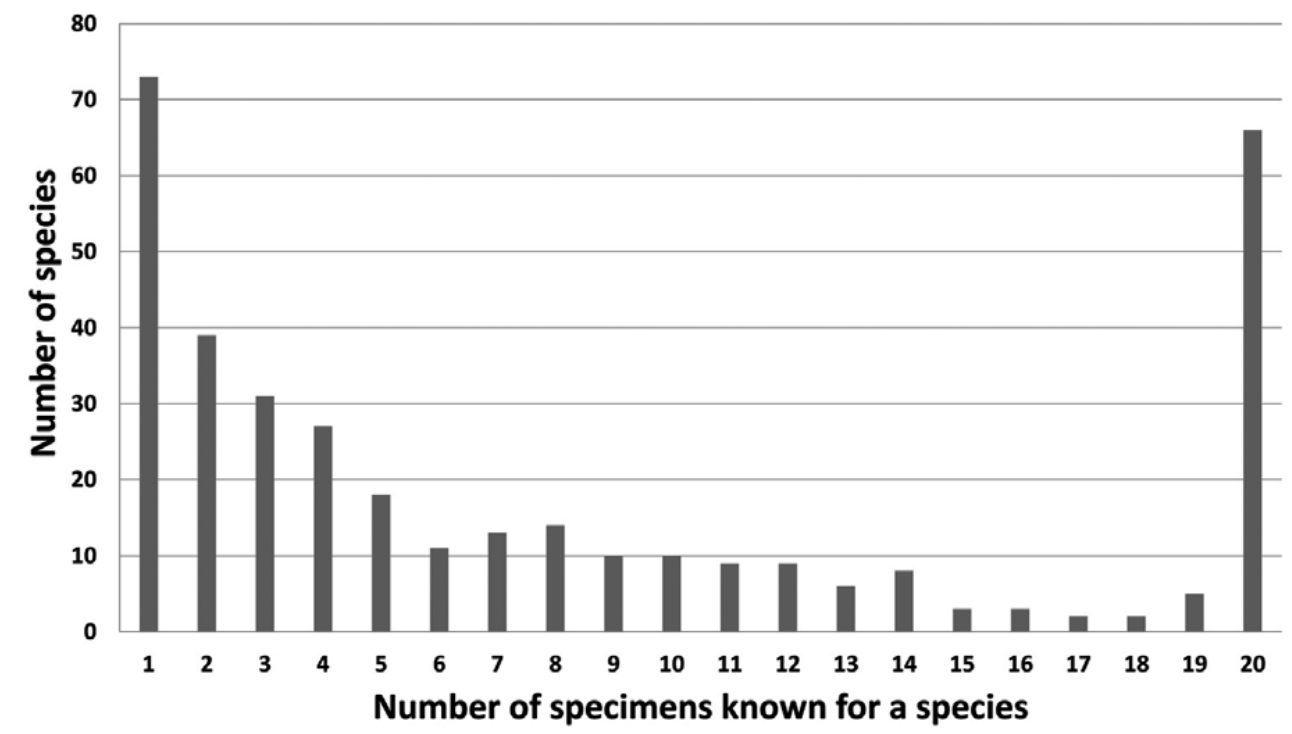

Fig. 3. Number of collections known (the 20 representing $\geq 20$ ) for each species from recent revisions of 359 species of Gesneriaceae. Data from Weber \& Burtt (1998), Hilliard \& Burtt (2002), Hilliard (2004), Middleton (2007, 2009a, 2016), Xu et al. (2008), Anderson \& Middleton (2013), Middleton et al. (2014, 2015), Bransgrove \& Middleton (2015), Puglisi \& Middleton (2017a, 2017b, 2017c, 2017d). Data from revisions of taxa from only restricted geographical areas are only included if the number of specimens from outside the area is known and incorporated.

far more undescribed species in Southeast Asia than previously appreciated. The Rauvolfioid and Apocynoid Apocynaceae fit into a pattern that is common in Asian woody plants of most species not being narrowly endemic and many species being very widespread. The Gesneriaceae, conversely, may be typical of plant families which have large numbers of narrowly endemic species and where very many species have yet to be described or even yet be collected. This could be the case in families or groups such as the Asclepiad Apocynaceae, Begoniaceae, Orchidaceae, Rubiaceae, Urticaceae and Zingiberaceae which still require considerable taxonomic work across Southeast Asia. In addition, Wong $(2016,2017)$ has also found that genera of treelets and understorey trees in Borneo, such as Melastoma L. and Saurauia Willd., are considerably more diverse than previously suggested. This is also indicated in ongoing revisionary work by Wong Khoon Meng with Chen Junhao on Timonius DC. (Rubiaceae) in Borneo. Estimates of species diversity for each of the Flora projects in Southeast Asia have largely been based on extrapolations of those plant families already revised which have so far not included enough of these hyper-diverse herbaceous and understorey woody families.

Our understanding of the flora of Southeast Asia is also limited by the infrequent flowering of many plant species. It is well known that many species of Strobilanthes Blume (Acanthaceae) flower only every 10 or more years (Wood \& Scotland, 2009). 
Consequently, several species of Strobilanthes have been collected only from the type localities. Many species of Fagaceae also exhibit synchronised supra-annual fruit production known as mast seeding (Sork, 1993; Kelly \& Sork, 2002) and thus it is not easy to collect good fruiting specimens of those species. Likewise, many tree species in Southeast Asia flower only after an irregular drought and low temperature, a phenomenon known as general flowering (Sakai, 2002; Chen et al., 2017). Nonsynchronised supra-annual flowering is also common among tree species in tropical rain forests (Sakai, 2002) and tropical seasonal forests (Kurten et al., 2017) in Southeast Asia. Due to these infrequent flowering events, it is to be expected that a considerable number of plant species have never been collected because botanists generally only collect fertile specimens. To overcome this limitation, Yahara et al. (2012) aimed to assess total plant diversity of plots by collecting all of the vascular plant species within each plot, including the sterile ones, and identify them by using DNA barcoding. They carried out this assessment in 56 locations in Southeast Asia and accumulated more than 44,000 specimens of about 30,000 species, including silica-gel dried leaves for molecular analyses. On Mt Bokor in Cambodia, for example, 770 species were reported (Tagane et al., 2017), among which only sterile specimens were collected for 260 species (34\%) in spite of intensive collection efforts over seven field surveys (Tagane et al., 2015a; Zhang et al., 2016). Among these 770 species, 24 species (3\%) were described as new species based on fertile collections, but another 40 species $(5 \%)$ remain undescribed due to the lack of fertile collections (Tagane et al., 2017).

Another factor which influences our understanding of plant diversity in any given region or locality is the focus of the collecting that has already been done there. The collection density for two regions may be similar but the kind of collecting done in each could still have a profound effect on our understanding of their relative plant diversities. In an analysis of the c. 8000 collections from the Mt Jaya area of New Guinea from 1913-1997, Utteridge \& De Kok (2007) found several patterns associated with collector bias during this period. The alpine and subalpine areas were most often visited and modern collectors only added a few additional species to the historic list of species; lowland and montane species-accumulation curves were still very steep showing that additional effort is needed in those habitats rather than more visits to the peak. Generalist collectors do not collect all species in an area, even if they know the flora well, and may not collect 'rare' species (or those species present at very low densities). Specialist collectors, however, are able to pick out rare species in species-rich and taxonomically difficult groups in the field, compensating for the systematic undercollection by generalists. Many herbaria struggle to balance the competing claims for resources put into databasing existing collections vs resources put into the collection of new material from poorly known regions. The key message from Utteridge \& De Kok (2007) is that databasing existing collections and serving these data online can directly lead to better use of resources in new collecting effort. This is because an analysis of the existing data allows for better planning with regard to the selection of specialist botanists and to understand which regions and habitats are already well collected. It was clear from the Mt Jaya data that botanists love to climb mountains, and whilst the peaks of Southeast Asia are extremely species-rich and at 
threat from climate change, it is the lowland and montane habitats that are most poorly collected and at most threat from immediate habitat conversion through logging and forest conversion to agricultural use such as oil palm.

\section{The Southeast Asian Flora projects}

We have shown above that, despite the poor collection density across much of Southeast Asia, huge numbers of new species are still being described from the region. It is highly likely that there are very many undescribed species already collected and in herbaria in the region and beyond (Bebber et al., 2010), but it is also the case that very many undescribed species have yet to be collected at all. Given these facts, it could be argued that the Flora projects in the region should be delayed in order to ensure a better representation of the true plant diversity of the region once we have had time to collect adequately throughout the countries of Southeast Asia and once we have had time to ensure that the taxonomic work has been done to describe the new species found. Whatever the merits of such an argument, it ignores the fact that we will always need to do more collecting and that the plant diversity could always be better known than it is now. This was always the case and will likely be so for a long time to come. We must always be aware of the limitations in our taxonomic works but future progress will always be better enabled when benchmarks are set and existing data synthesised into manageable forms using the latest available techniques and taxonomic/systematic ideas. This is what Floras are for and even if they do not allow us to account completely for the plant diversity of the regions they cover, they can alert us to the possibility of new taxa and expanded distributions.

With these caveats, the existing and aspiring Flora projects in the region are discussed in this paper. We present here progress on the major Southeast Asia Flora projects: the Flora of Thailand, the Flora of Cambodia, Laos and Vietnam/Flore du Cambodge, du Laos et du Viêtnam, Flora Malesiana, Flora of Peninsular Malaysia, Tree Flora of Sabah and Sarawak, Flora of Singapore and Flora of Vietnam. We also separately present an overview of plant diversity research and plans for the future in the countries not covered by these Floras (only Myanmar) or when the Flora projects which include them are transnational and there is more to say on a national or subnational level.

\section{Flora of Thailand}

The first scientific plant collections from Thailand were made by Koenig in 1778 and very few were made thereafter until the early twentieth century (Kerr, 1939). Curtis collected in Peninsular Thailand sporadically between 1889 and 1899, followed by Ridley who described a number of new taxa from areas that are now in Thailand (Ridley, 1920). At the time Kerr began his collecting activities it is estimated that there were only 4250 collections from the whole of Thailand. Kerr himself collected over 
21,500 specimens from all parts of the country and by the time he left Thailand in 1932, and along with the collections from his associates, it is estimated that the total number of specimens from Thailand had grown to 35,000 (Jacobs, 1962). These collections were worked up by Craib, Kerr and people who worked with them and resulted in the description of large numbers of new species and the Florae Siamensis Enumeratio (see Jacobs, 1962). After Kerr retired there was little collecting or taxonomic research until the Royal Forest Department started new collecting activities in the 1950s under the direction of Tem Smitinand. From the late 1950s, Danish and other international botanists began a long and ongoing collaboration with Thai botanists on the plant diversity of Thailand that led to the launch of the Flora of Thailand project in 1967 and publication of the first volume in 1970 (Middleton, 2003b). To date, 46 parts have been published which include about $60 \%$ of the estimated 11,000 species of vascular plants in Thailand. Progress in the early years was faltering but parts have appeared every year since 2007 (Fig. 4) and all remaining families are under active research and compilation. The Board of the Flora of Thailand has the ambitious aim of having the entire Flora completed by 2024. Middleton (2003b) commented on the much greater involvement of the Thai botanical community, along with international researchers, compared to several other Flora projects in Southeast Asia in which far fewer accounts were written by botanists based in the region. Since 2003, Thai authorship of accounts has continued to increase. The importance of North-South collaboration in Flora writing has also been discussed by Newman et al. (2017).

Alongside the printed Flora of Thailand accounts, there have been several online projects such as the Ferns of Thailand, Laos and Cambodia (Lindsay \& Middleton, 2012 onwards) and the Flora of Thailand Euphorbiaceae (Van Welzen \& Chayamarit, 2017).

There is also a large Thai language botanical literature and both Thai and English language botanical journals that record the progress of research on plant diversity in the country. A guide to Thai plant names has also been published (Smitinand, 2014). As well as the Flora of Thailand itself, there is a large body of literature that documents the diversity of particular plant groups in Thailand (e.g. Puff et al., 2005; Larsen \& Larsen, 2006) or the diversity of regions and national parks (Phengklai \& Niyomdham, 1991; Chayamarit \& Puff, 2006, 2007a, 2007b). Of particular note are the very detailed and well-illustrated books on the trees of northern and southern Thailand by Gardner et al. $(2000,2015,2016,2018)$ that were published in both Thai and English.

The conservation needs of plants in Thailand have been highlighted in many works such as Santisuk et al. (1991) and Pooma (2005).

In Thiers (continuously updated), 15 herbaria are listed for Thailand. Most of these herbaria are associated with universities where they contribute to training future generations of botanists. The largest herbaria are BKF with an estimated 280,000 specimens, QBG with 110,000 specimens and BK with 65,000 specimens.

Parnell (2000) assessed the collection density in Thailand at 50 collections per $100 \mathrm{~km}^{2}$. If one adds up the number of collections stated for each herbarium in Thailand from Index Herbariorum (Thiers, continuously updated) then the collection density for Thailand is around 100 collections per $100 \mathrm{~km}^{2}$. There will, of course, be 


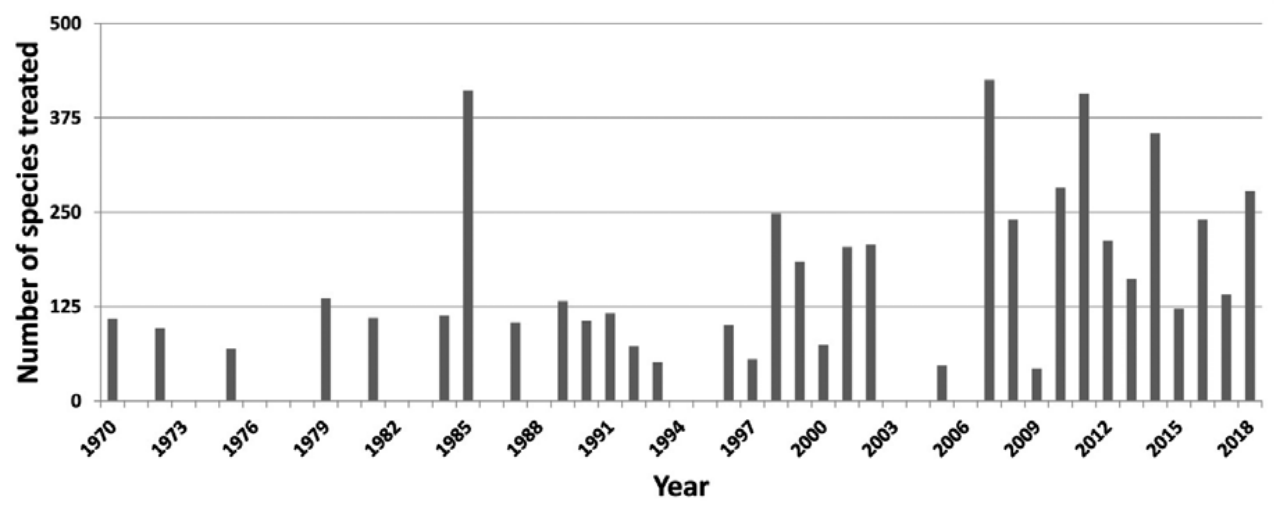

Fig. 4. Number of species published per year in the Flora of Thailand.

a large overlap of duplicates between these herbaria and collections outside Thailand but additionally there will be some collections outside Thailand that are not duplicated in a Thai herbarium. We, therefore, estimate a collection density for Thailand of approximately 75 collections per $100 \mathrm{~km}^{2}$ (Table 2).

\section{Flora of Cambodia, Laos and Vietnam / Flore du Cambodge, du Laos et du Viêtnam}

Much of the early history of botanical collecting and publication in Cambodia, Laos and Vietnam is laid out in the preliminary volume to the Flore générale de l'Indochine (Gagnepain, 1944) and a brief account of the completion of this work is given in the first fascicle of the Flore du Cambodge, du Laos et du Vietnam (Aubréville, 1960).

The first botanical publication was Loureiro's Flora Cochinchinensis, published in Latin at Lisbon in 1790. At the time the term Cochinchina meant something close to the whole Indo-Chinese continental region. Loureiro himself lived at Hue so most of the plants he treated came from central Annam, to which he added species from China, India and the east coast of Africa.

The principle collectors in the $19^{\text {th }}$ and early $20^{\text {th }}$ centuries were French. Joseph Baume (born 1810) may be the earliest. A few of his collections made in 1833 in Hue and Danang (Tourane) are still held at the herbarium of the Muséum Nationale d'Histoire Naturelle in Paris. In the 1860s and 1870s, Clovis Thorel (1833-1911) made more than 5000 collections in Cambodia and southern Laos while the most prolific collector of the colonial period was Eugène Poilane (1887-1964) who gathered more than 32,000 specimens.

The next significant publication to follow the Flora Cochinchinensis was the Flore forestière de la Cochinchine (Pierre, 1880-1907). A decree of June 1877 put Jean Baptiste Louis Pierre, the Director of Saigon Botanic Garden, in charge of both the Flore forestière and the Flore générale de l'Indochine. The former, as the name 
suggests, treated trees of Cochinchina which by this time meant only southern Vietnam. The Flore forestiere was never completed and, at Pierre's death in 1905, none of the Flore générale de l'Indochine had been published.

Responsibility for the Flore générale de l'Indochine then passed to the Muséum national d'Histoire naturelle in Paris where François Gagnepain and Achille Eugène Finet were the editors for a short time until Henri Lecomte was made professor at the museum. Lecomte became director of the Flore and Gagnepain became editorial secretary. From 1907-1951, the entire flora of Cambodia, Laos and Vietnam was revised in the Flore générale de l'Indochine.

Supplements to the families revised in volume 1 of the Flore began to appear in 1938 and continued until 1950, after which there was a pause in publication. When it resumed in 1960, the name was changed to the Flore du Cambodge, du Laos et du Viêtnam (Aubréville, 1960).

Thirty-two volumes of the Flore $d u$ Cambodge, du Laos et du Viêtnam were published by the Muséum from 1960-2004 and then there was another pause of ten years before a co-publication agreement was signed between the Muséum and the Royal Botanic Garden Edinburgh which resulted in the publication of volumes 3335 (Apocynaceae, Polygalaceae and Solanaceae). A new co-publication agreement, including the Institut de Recherche pour le Développement (IRD), was signed in 2017 to publish volume 36, the Convolvulaceae. This volume came out in November 2018, bringing the number of families, genera and species published so far to 83, 606 and 2310 respectively (Fig. 5).

\section{Flora Malesiana}

The Flora Malesiana (FM) project was initiated in the 1940s by Van Steenis in Bogor, Indonesia, initially as a Flora of Indonesia. His analysis of generic distributions led him to broaden the scope to the entire Malesian region - Brunei Darussalam, Indonesia, Malaysia, Papua New Guinea (excluding the Bismarck Archipelago, Buka and Bougainville), Philippines, Singapore and Timor Leste (Van Steenis, 1950). The idea of a floristic study of the region had earlier also been proposed by Zollinger (De Wit, 1949). The Foundation Flora Malesiana was established in 1991. The Board of the Foundation includes representatives of major Malesian botanical institutes and contributing institutes overseas. The Board is chaired by an Indonesian representative from the Indonesian Institute of Sciences (LIPI) and the vice-chair is from the Naturalis Biodiversity Center in Leiden.

The primary output of the project includes 42 Flora instalments on seed plants (bound in 23 volumes) and eight instalments on ferns and fern allies (bound in four volumes), as well as nine CD-ROMs, in total treating more than 12,400 species in detail (Fig. 6). All family treatments published in the series have been made available online as PDFs or, for contents of the original CD-ROM series, as webpages by the Naturalis Biodiversity Center (see links at floramalesiana.org). In addition, some ongoing revisionary work for the project is presented on taxon-specific webpages, e.g. 


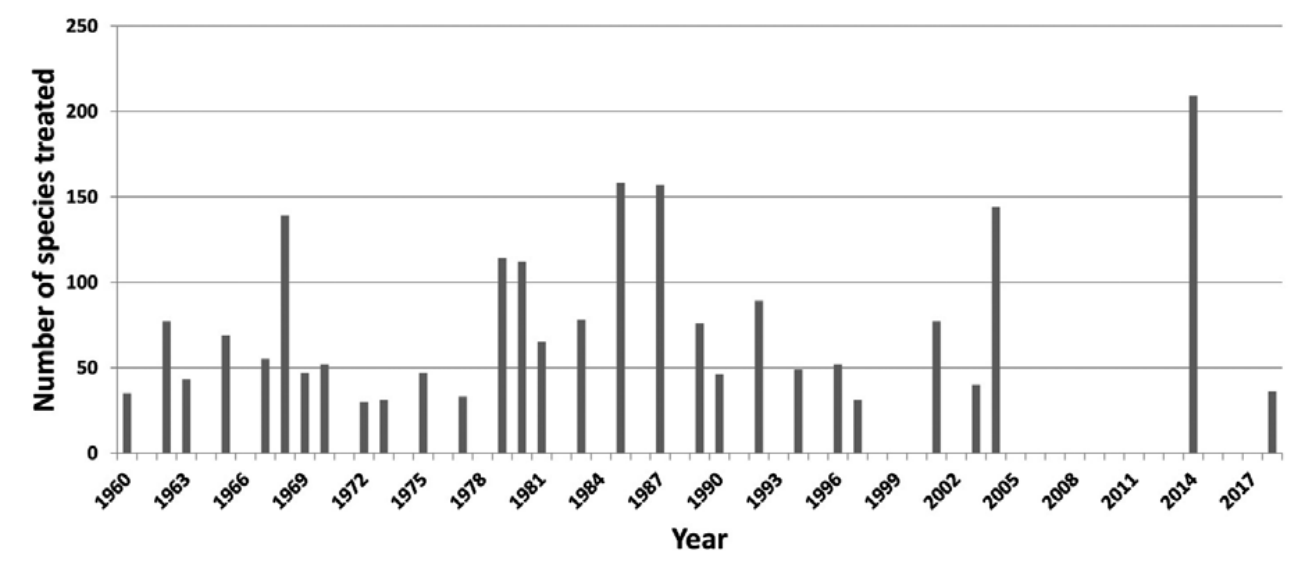

Fig. 5. Number of species published per year in the Flore du Cambodge, du Laos et du Viêtnam.

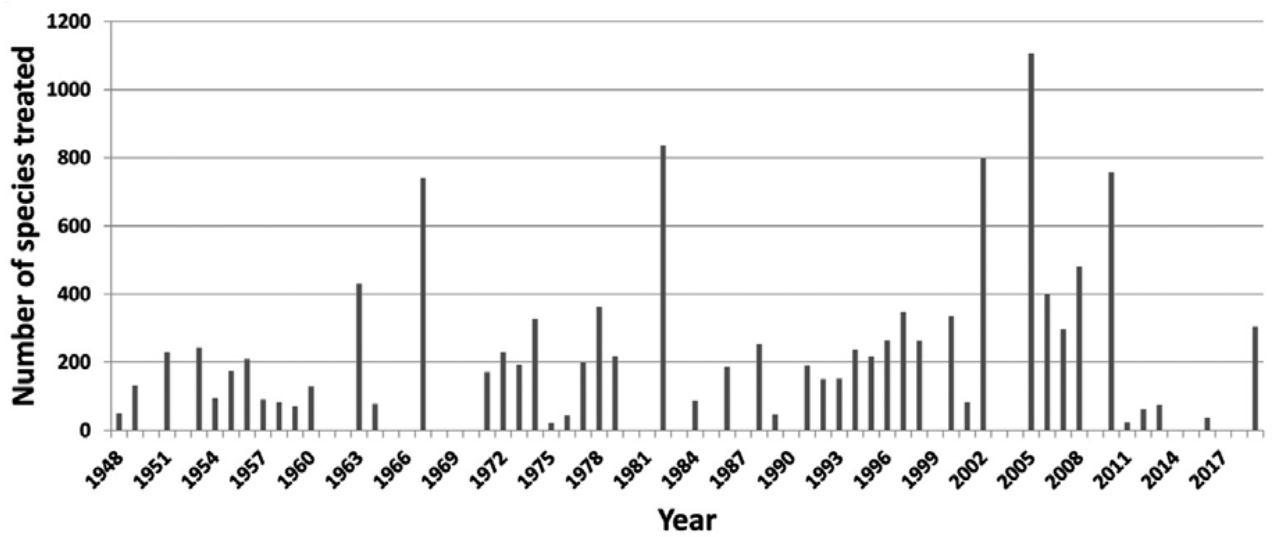

Fig. 6. Number of species published per year in Flora Malesiana

Euphorbiaceae of Malesia (Van Welzen, continuously updated: currently featuring more than 700 species descriptions). Flora Malesiana Symposia have been held every three years since 1989 providing a forum and networking platform for plant scientists and key regional stakeholders interested in the taxonomy, systematics, ecology and conservation of the Southeast Asian flora. Seven proceedings of FM Symposia have been published (see floramalesiana.org for references).

Current Flora Malesiana publications cover only about $29 \%$ of the vascular plant species diversity of Malesia (estimated at 45,000 species by Corlett \& Primack, 2011) and this incompleteness, and the relatively slow progress, has limited the Flora's impact on aspects such as conservation and land use planning in the region. However, much additional information on the Malesian flora already exists in a large but fragmented body of detailed species-level data in regional floras and the scientific literature. To mobilise and present this data, pilot projects in the FM framework have 
explored the use of database backbones dynamically linked to website output, mark-up procedures to populate these databases mobilising data from both digitalised legacy literature (earlier FM volumes) and digitally-born (more recent Flora volumes and journal articles) data sources (Flora Malesiana Working Group, 2011 onwards; De Wilde, 2014; Hamann et al., 2014; Penev, 2014), and platforms allowing remote online collaboration and data sharing for Flora contributors (Hovenkamp \& Cicuzza, 2013; Thomas et al., 2013).

Roos (2003) emphasised the fact that progress on the Flora Malesiana project has heavily relied on institutional commitment in the Netherlands, and, to a lesser extent, from other European institutions, while contributions coordinated by researchers from Malesian botanical institutions have been sporadic (but see Soepadmo, 1973; Keng, 1978). This situation has not much improved since 2003, but a FM secretariat branch has been established at Singapore Botanic Gardens (Thomas \& Roos, 2016) and researchers from Brunei, Malaysia and Singapore have recently taken on roles as taxon treatment coordinators for the project (see floramalesiana.org for a list of families still to be revised and current taxon treatment coordinators). As the number of taxonomists has been decreasing at some of the major European botanical institutes supporting FM, however, further strengthening of the representation and contributions from the Malesian region will be crucial for the project. Institutional commitment in the region and increased efforts to secure funding for the project at institutional, national and international level, in combination with technological innovation in the presentation and accessibility of available data, are clearly needed to accelerate the project's progress.

\section{Flora of Peninsular Malaysia}

A phased approach to document the flora of Malaysia has begun with two projects: the Flora of Peninsular Malaysia project and the Tree Flora of Sabah and Sarawak project (Saw \& Chung, 2007, 2015).

Peninsular Malaysia has about 8300 species of vascular plants. The history of discovery and description of plant species in what is now Peninsular Malaysia is well known (Parris et al., 2010; Kiew et al., 2010; Saw \& Chung, 2007, 2015) from the early colonial days centred on Penang, to the extensive collections by Griffith, Kunstler, Scortechini and Maingay, among others, that were sent to Calcutta, Kew and elsewhere and which were the basis of King \& Gamble's Materials for a Flora of the Malayan Peninsula (originally published in the Journal of the Asiatic Society of Bengal). From the late nineteenth century, plant exploration and description of new species blossomed in Singapore Botanic Gardens under H.N. Ridley's direction. Ridley himself collected over 50,000 specimens and described over 4000 species and, in his retirement at Kew, wrote the five volume Flora of the Malay Peninsula (Ridley, 1922-1926), largely based on the Materials but including information from his wide field experience. Ridley's example in Singapore Botanic Gardens was followed by Holttum, Corner, Carr and Henderson amongst others. 
After the Second World War, the focus of botanical collecting gravitated to the Forest Research Institute at Kepong where the herbarium was developed by Foxworthy followed by Symington and Wyatt-Smith who employed the first local botanist, K.M. Kochummen. In 1965, the Tree Flora of Malaya project was launched with T.C. Whitmore as editor and contributor along with Kochummen for the first two volumes (Whitmore, 1972, 1973). The subsequent two volumes were edited by F.S.P. Ng who completed the Flora in 1989 based on accounts by staff in Kepong and Malaysian universities (Ng, 1978, 1989). The checklist by Turner (1997) is extremely helpful for a wider audience to keep up with the many name changes since the publication of the Tree Flora of Malaya. Unfortunately, it has not been updated since 2003.

The Flora of Peninsular Malaysia was launched in 2005 with funding from the Ministry of Science, Technology and Innovation (MOSTI) which included the employment of young botanists. It aimed not only to provide up-to-date accounts but to be an improvement on previous Floras and checklists in its provision of comprehensive citations pertinent to Peninsular Malaysia, the citation of types for accepted names and synonyms, distribution maps, conservation statuses, botanical plates and photographs (Kiew \& Rafidah, 2007). Facilities for the Flora include:

1. The Kepong herbarium, which is effectively the National Herbarium of Peninsular Malaysia. At present it houses more than 350,000 specimens, including many duplicates of species collected in Sabah and Sarawak. There are 1286 type specimens. The Singapore Herbarium remains crucial because most of the early collections from Peninsular Malaysia are housed there. There are also a number of important university herbaria.

2. Ongoing collecting which supplements the herbarium and which focuses on (a) collecting poorly known localities, (b) specialist collecting for work on taxonomic revisions, and (c) revisiting original localities to check on the conservation status of rare and endangered species. The Flora of Peninsular Malaysia team carries out regular field trips and specimens are accumulated at the rate of between 1000-2000 specimens a year. The focus has been on the limestone flora in part because the demand for cement has resulted in licences for mining karst hills being issued before detailed botanical inventories can be carried out and partly because in 2017-2019 the Ministry of Water, Land and Natural Resources (KATS) is funding a systematic botanical survey of karst hills in Kelantan and Perlis.

3. Computerisation, which aids work on taxonomic revisions in two ways. The first is that BRAHMS (Botanical Research And Herbarium Management System) facilitates herbarium management and specimen databasing; the second is that type specimens and many of the older protologues are now available online.

The Flora is produced in two series: Series I for ferns and lycophytes and Series II for seed plants. It is published in hard copy with about 100 species per volume. Since 2010, two volumes of Series I have been published with 213 species altogether, representing about a third of the 632 species in Peninsular Malaysia (Parris et al., 2010, 2013). Since 2010, seven volumes of Series II have been published with 781 species altogether, representing about $10 \%$ of the 7570 named species (Kiew et al., 2010, 2011, 2012, 2013, 2015, 2017, 2018). The Flora has benefited from the long experience of 
specialists, many of whom have completed revisions for Flora Malesiana, such that a total 736 species (74\% of the total of 994 species) has been contributed by these specialists.

Field work in areas that are botanically poorly known has continued to reveal new species. At least 95 new species have been published in recent years with more currently under investigation. The relatively small number of recent new species (95 out of 8300 species) might suggest that the flora is well known. However, genera that are poorly known botanically are likely to generate a large proportion of new species, as illustrated by the revision of Thottea Rottb. (Artistolochiaceae) where nine of the 16 species are new to science (Yao, 2015), and many of these poorly known genera are yet to be revised.

Progress on many families has been greatly facilitated by Flora Malesiana revisions. The problem is going to arise when it comes to revising large families with more than a hundred species, many of which do not have adequate recent revisions. These include Acanthaceae, Araceae, Arecaceae, Clusiaceae, Euphorbiaceae, Gesneriaceae, Melastomataceae, Myrtaceae and Rubiaceae, altogether representing about a quarter of the Peninsula's species. The largest family, Orchidaceae with 920 species (Ong et al., 2017), is a prime example of this.

This raises the interesting question of how many species it might be reasonable to expect a taxonomist to produce in a year. The productivity record undoubtedly belongs to H. Sleumer (Kiew, 1984) who could produce taxonomic descriptions of 250 species per year. In Malaysia, the most productive botanist so far has been K.M. Kochummen, who after many years' experience in the herbarium, was able to produce 40-50 species per year for the Tree Flora of Malaya and the Tree Flora of Sabah and Sarawak. Saw \& Chung (2007) planned for ten botanists to each produce 20 species a year to enable the Flora of Peninsular Malaysia to be completed in 20 years. This rate of productivity, however, has not been reached and the Flora still largely relies on contributions from overseas specialists.

Another bottleneck in the production of the Flora is the dearth of scientific editors. This will shortly be overcome when two more editors become active (R.C.K. Chung for Lauraceae, 214 species, and Y.Y. Sam for Gramineae, 238 species).

National conservation assessments using IUCN Criteria and Categories are included for all species in the Flora. To date, 1008 indigenous species have been assessed of which about a quarter (24.8\%) are threatened (66 Critically Endangered, 88 Endangered and 97 Vulnerable), 52.3\% (527 species) are of Least Concern, 16.4\% (166 species) are Near Threatened and 6.3\% (64 species) are Data Deficient. For the Flora, the bar for considering a species to be Extinct in the Wild is extremely high and requires returning to the type locality and all possible similar habitats before it can be considered possibly Extinct. For example, Combretocarpus rotundatus (Miq.) Danser was published as 'probably extinct' by Kochummen (1989) because the peat swamp where it grew was cleared for agriculture but was reassessed as Data Deficient in the Flora (Nor-Ezzawanis, 2018). It is likely that the majority of the 'DD species' are in fact 'probably extinct'. So far only three species are recorded as Extinct in the Wild, namely two ferns, Oreogrammitis crispatula (Holttum) Parris and O. kunstleri Parris, and Pisonia grandis R.Br. 


\section{Tree Flora of Sabah and Sarawak}

Sabah and Sarawak have an estimated 12,000 species. Sabah and Sarawak lacked the collection intensity of Malaya in the early years but in recent years the Forest Research Centres in Sandakan and Kuching have been steadily increasing their collections. Wong (1995) has amply summarised the collection history and publication history of the Bornean flora in the introductory chapters of the Tree Flora of Sabah and Sarawak Volume 1.

For Sabah and Sarawak, until the initiation of the Tree Flora of Sabah and Sarawak project, the only applicable and accessible references for most plant identification and information were the Flora Malesiana publications. Earlier, Merrill (1921) and Masamune $(1942,1945)$ had both published checklists of Bornean plants but these are of limited scope. Few other references are available for the documentation of the flora of Sabah and Sarawak except for the short accounts or forester's manuals of common or selected forest trees (Browne 1955; Smythies, 1965; Burgess, 1966; Cockburn, 1976, 1980; Anderson, 1980; Ashton, 1988). The Plants of Kinabalu project led by J. Beaman was published in five volumes (Parris et al., 1992; Wood et al., 1993; Beaman \& Beaman, 1998; Beaman et al., 2001; Beaman \& Anderson, 2004). Modern identification manuals, amounting to floristic enumerations, of the rattans of Sabah and Sarawak (J. Dransfield, 1984, 1992), and the bamboos of Sabah (S. Dransfield, 1992) have also been published. More charismatic groups such as orchids and Nepenthes continue to attract interest with publication of the Checklist of the Orchids of Borneo (Wood \& Cribb, 1994), Slipper Orchids of Borneo (Cribb, 1997), Orchids of Borneo (Beaman et al., 2001), and Nepenthes of Borneo (Clarke, 1997). The richly illustrated Etlingera (Zingiberaceae) of Borneo (Poulsen, 2006) and Rhododendron (Ericaceae) of Sabah (Argent et al., 2007) have also been recently published.

The Tree Flora of Sabah and Sarawak was launched in 1991 (Soepadmo \& Wong, 1995). Eight volumes have so far been published (Soepadmo \& Wong, 1995; Soepadmo et al., 1996; Soepadmo \& Saw, 2000; Soepadmo et al., 2002, 2004, 2007 , 2011, 2014). In the first eight volumes, 2235 indigenous tree species from 331 genera in 78 families are included. This figure represents about $64 \%$ of the estimated total of 3500 tree species native to Sabah and Sarawak. Of the tree species revised so far, 308 $(14 \%)$ are tree taxa new to science, and 1071 (48\%) are endemic to Sabah and Sarawak and/or Borneo. It is likely that at least another ten years will be needed to complete the remaining $1265(36 \%)$ species.

\section{Flora of Singapore}

The vegetation of Singapore has been more radically changed than that of any other country in Southeast Asia. By the time that Nathaniel Cantley was in charge of Singapore Botanic Gardens in the late nineteenth century, only 7\% of the primary forest remained (Cantley, 1884). Forest cover continued to decline until only around $0.3 \%$ of the original remained (Yee et al., 2011). The primary forest patches on Bukit 
Timah and in the Central Catchment are now mostly surrounded by secondary forest, much of it already fairly mature (Yee et al., 2019). This history of vegetation change accounts for the large number of plant species presumed nationally extinct or nationally threatened (Davison et al., 2008; Davison, 2019; Lim et al., 2019).

The earliest verified collections from Singapore are those of Smith from 1796 and William Jack from 1819 although there are also undated collections from a collector only known as Daud in Wight's Herbarium that are presumed to have been collected in 1818-1819, and from John Prince who sent specimens from Singapore to Wallich in 1819 (Van Steenis-Kruseman, 1950; Middleton \& Turner, 2019). Cowan (1954) noted that there was a specimen collected by Archibald Menzies from Singapore in the Royal Botanic Garden Edinburgh but did not state what it was and it has not subsequently been located. Menzies is likely to have been in Singapore in 1789 which would make his the earliest collections. Nathaniel Wallich came to Singapore in 1822 and spent five months collecting and helping to establish the first botanic garden at what is now Fort Canning. His were the first extensive collections from Singapore but from then until Henry Ridley arrived in 1888 the collections were rather few despite the establishment of the Botanic Gardens in 1859 and the many visiting European collectors or those passing through on their way elsewhere (Van Steenis-Kruseman, 1950; Middleton \& Turner, 2019). Ridley, however, was an extremely prolific collector — Van SteenisKruseman (1950) noted that he collected about 50,000 numbers, of which about 8000 are from Singapore (Middleton \& Turner, 2019). He also described several thousand new species and had a huge publication output (Middleton \& Turner, 2019). Collecting in Singapore has ebbed and flowed since but as the country is small the cumulative effect of the collecting has been to make Singapore arguably the most densely collected country in the world. Niissalo et al. (2014) gave the collection density as 5721 collections per $100 \mathrm{~km}^{2}$.

There have been a number of checklists published for Singapore (Ridley, 1900; Turner, 1993; Chong et al., 2009) and also a concise Flora (Keng, 1990; Keng et al., 1998). The most complete floristic treatment, however, remains Ridley's Flora of the Malay Peninsula (Ridley, 1922-1925), which included Singapore, although this did not include bryophytes or pteridophytes. A new Flora of Singapore has been initiated by Singapore Botanic Gardens and three volumes have so far been published (Middleton et al., 2019a,b,c). Over the coming years, 11 more volumes on bryophytes and vascular plants will be published to encompass the estimated 3146 native, naturalised and casual species found in Singapore (Middleton, 2019).

\section{Additional national floristic activities}

\section{Myanmar}

At $676,578 \mathrm{~km}^{2}$ Myanmar is the largest country in continental Southeast Asia with the greatest breadth, spanning both the tropics and the subtropics across 18 degrees of latitude. It hosts a wide range of terrestrial ecosystems from wet tropical forest and coastal mangroves in the south, to arid scrub in the central dry zone, to montane 
subtropical and temperate forests in the north, culminating in alpine meadows in the vicinity of Hkakaborazi $(5881 \mathrm{~m})$, Southeast Asia's highest peak. Floristically, Myanmar is at the crossroads between South Asia, East Asia and Indochina, with influences from each adjacent region - from the Sino-Himalayan flora in the far north, the Yunnanese flora in the northeast, the Assamese flora in the northwest, the ThaiIndochinese flora in the southeast, and the Malesian flora in the southern peninsular region of the country. Consequently, the flora of Myanmar is exceptionally diverse. The most recent version of the Myanmar checklist (Kress et al., 2003) includes 273 families, 2371 genera and over 11,800 species of spermatophytes. Our revised current estimate of the number of vascular plants (including ferns and lycophytes) is of the order of 16,000 species.

The first known herbarium collections from Myanmar were made in 1763 by missionaries (Biswas, 1943). In 1795, Francis Buchanan-Hamilton collected along the banks of the Irrawaddy (Ayeyarwady) river. He was followed by Nathaniel Wallich in 1824, Hugh Falconer from 1830-55, and William Griffith in 1833. Other notable collectors include Jan Vilem Helfer during 1836-1840, Deitrich Brandis during 185664, W. Sulpiz Kurz during 1864-78, Andrew Gage during 1898-1904, and John H. Lace during 1904-1913, all of whom focused their efforts on documenting woody species in central and southern Myanmar in connection with the Burmese Forest Department.

Plant collecting in northern Myanmar (i.e. in Shan and Kachin states) commenced following the annexation of 'Upper Burma' by the British following the Third AngloBurmese war in 1885. Prominent collectors during this phase of exploration were E. Pottinger in 1867 and Shaik Mokim during 1897-1903. They were followed by 'plant hunters' in search of garden-worthy plants for the British horticultural trade, and include George Forrest during 1912-14, Reginald Farrer \& Euan Cox during 1919-1920, Joseph Rock in 1922 and the most prolific collector of all, Francis Kingdon-Ward, who made about 12 expeditions to northern Myanmar between 1919 and 1956 and greatly expanded our knowledge of the northern Myanmar flora. F.G. Dickason (in 1938), Tha Hla \& Chit Ko Ko (1942-54), James Keenan (1961-62) and Maung Gale (1962) all made important contributions to the collections from a variety of localities throughout the country (Watson \& Smith, 2004). In particular, Dickason's research resulted in the publication of Ferns of Burma (1946), the first attempt at a national checklist for the group. After the Second World War botanical investigations decreased and by 1967 collecting had practically ceased. However, more recently several international botanical institutions have begun inventory programmes, including the Smithsonian, Makino Botanical Garden, New York Botanical Garden, the Korean National Institute of Biological Resources, the National Museum of Nature and Science, Tokyo, and the Chinese Academy of Sciences.

The Kochi Prefectural Makino Botanical Garden (MBK) began its ongoing inventory programme in collaboration with the Myanmar Forest Department in 2000, with expeditions to Chin, Shan, Kachin, Kayin, Sagaing and Mandalay States and Regions. Thus far, a total of 30,640 specimens have been collected by a collaborative team of local and international botanists through MBK's project. Numerous new 
species have been described as a part of this effort and a checklist of the flowering plants of Mt Popa was published (Tanaka et al., 2006). Makino Botanical Garden's research has also focused more specifically on documenting the flora of Natma Taung (Mt Victoria) in Chin State: two guidebooks have been published (Fujikawa et al., $2008,2015)$ and a taxonomic enumeration of the area is forthcoming.

Between 1996 and 2003 the Smithsonian Institution and the Forest Research Institute in Myanmar conducted a number of botanical field trips to a variety of protected areas throughout the country. This collaboration culminated in the most recent update of 'the Checklist' (Kress et al., 2003). Additionally, ongoing research led by Singapore Botanic Gardens has resulted in A Guide to Orchids of Myanmar (Kurzweil \& Lwin, 2014), and a taxonomic checklist of Orchidaceae of the country is forthcoming.

In 2013, Marburg University began an ecological project in Hponganrazi (Kachin State), and Natma Taung (Chin State), which involved extensive specimen collection. This research has resulted in the publication of a taxonomic list of ferns and lycophytes from these localities (Khine et al., 2017).

The New York Botanical Garden's research in Myanmar began with expeditions in 2004, 2005 and 2009 to document rattan species in the Hukaung valley (Kachin State) in collaboration with the Wildlife Conservation Society and the Myanmar Forest Department. This research culminated in the publication of the taxonomic guidebook Rattans of Myanmar (Henderson \& Peters, 2018). New York Botanical Garden began further botanical inventory programmes in Htamanthi Wildlife Sanctuary (Sagaing Region) during 2014 and in Hkakaborazi National Park and Hponganrazi Wildlife Sanctuary (Kachin State) during 2015. Both of these projects are ongoing and aim to produce specimen-based species checklists of the protected areas.

The Korean National Institute of Biological Resources has been collaborating with the Myanmar Forest Department since 2011, including biodiversity inventories in Natma Taung National Park and southern Shan State. As a result, many new records of vascular plants for Myanmar have been reported (Kang et al., 2017a, 2018), and Seed Plants of Natma Taung National Park was published (Kang et al., 2017b), in which 600 species in 120 families were illustrated.

Since 2014 the Chinese Academy of Science, led by Xishuangbanna Tropical Botanical Garden, has been carrying out fieldwork in Hkakaborazi National Park and Hponganrazi Wildlife Sanctuary, and a number of new species have been described based on their collections.

The National Museum of Nature and Science, Tokyo and the Myanmar Forest Department, began a new botanical inventory project in 2016 in order to contribute to the Flora of Myanmar. Since then, 14 expeditions have been conducted, primarily to under-collected regions of southern Myanmar.

The most substantial herbarium collections within Myanmar are held at the herbarium of the Forest Research Institute (RAF) in Yezin. It was originally founded in Rangoon in 1925, and was then known as the Burma Forest Herbarium. Following the establishment of the Forest Research Institute in Yezin during 1978, the specimens were moved, with assistance from UNDP and FAO, and incorporated into FRI's collections. 
Tha Hla, Chit Ko Ko, Keenan, and Maung Gale's specimens form the basis of the collections, with additions from Daw Yin Yin Kyi and forestry students from the 1980s to the early 2000s. The RAF herbarium is currently in the process of being rebuilt at FRI by the Japan International Cooperation Agency. Outside Myanmar the following foreign herbaria have the most significant holdings of historical specimens: Kew $(\mathrm{K})$, Edinburgh (E), British Museum (BM), Harvard (A/GH), New York (NY), Calcutta (CAL), Dhera Dun (DD), and more recent collections can be found at the Smithsonian (US), Makino Botanical Garden (MBK), Japanese National Museum of Nature and Science (TNS), Beijng (PE), Xishuangbanna Tropical Botanical Garden (HITBC), and the Korean National Institute of Biological Resources (KB).

Several Myanmar plant lists were developed as part of colonial efforts to document the flora of British India. The first of these was Mason (1851), followed by Kurz (1877) and Pottinger \& Prain (1898). Both Hooker (1872-1897) and Brandis (1906) also included Burmese species. These were followed by Lace (1912). The text of this work was subsequently revised four times by Rodger (1922), Hundley \& Chit Ko Ko (1961), Hundley (1987) and Kress et al. (2003). Two other important regional species lists are Merrill (1941) and Nath (1960).

Despite these early efforts, the flora of Myanmar remains understudied. Frodin (2001) correctly stated that 'Considerable parts [of the country] remain botanically not at all or poorly known; moreover much of the collecting done until then [1962], particularly after the Second World War, has not been reported upon, or only haphazardly so. Of all of tropical Asia it has had the smallest proportion of its flora collected.'

Although collecting density is quite difficult to gauge, we estimate, based on historical and current collection programmes, that it is approximately 20 specimens per $100 \mathrm{~km}^{2}$. While there have been repeated and concentrated collecting efforts in some areas of the country (e.g. Natma Taung in Chin State and northern Kachin State), other regions remain under-collected, such as Kayah and Kayin States in the southeast, northern Shan State in the east, Rakhine State in the southwest, northern Chin State in the west, and northern Sagaing Region and adjacent southwest Kachin State in the northwest. Current estimates (Table 2) concur with the assessment by Frodin (2001) that Myanmar is poorly collected although Cambodia and Laos have lower estimated collecting densities.

In March 2013 an Institutional Consortium for Floristic and Economic Botanical Research in Myanmar (FoMIC = Flora of Myanmar Institutional Consortium) was convened by the Myanmar Forest Department, with the intention of working towards assembling the Flora of Myanmar. A second meeting was held in September 2014. However, this movement stalled because a multilateral Memorandum of Agreement was not completed. Since then, the first Meeting of the Flora of Myanmar was organised by the Myanmar Forest Department in December 2017, and the second meeting was held a year later, in 2018. During the second meeting, the publication of the Flora of Myanmar was discussed (i.e. the editorial committee, project plan and budget), and it was decided that the project would proceed according to a 40 year plan. The first editorial committee meeting will be held in 2020 in conjunction with the opening ceremony of the new RAF herbarium building. 


\section{Cambodia}

Early botanical collecting and research activities in Cambodia are discussed above in the context of work that preceded the Flore du Cambodge, du Laos et du Viêtnam although it should be noted that Cambodia received far less attention than Vietnam in these early efforts. In addition, decades of political instability made collecting and botanical study almost impossible, leading to the collection density for the country being very much lower than for most countries in the region except Laos. More recently, collecting programmes and associated botanical research have been revived through the efforts of the Royal University of Phnom Penh (RUPP in Thiers, continuously updated) and other Cambodian bodies, along with international organisations, universities and NGOs with which they are collaborating. Publications arising from such collaborations include Flore Photographique du Cambodge (Leti et al., 2013), papers in the Cambodian Journal of Natural History (https:/www.fauna-flora.org/ publications/cambodian-journal-natural-history), and other publications (e.g. Kim et al., 2012).

Kyushu University, Japan, has been collaborating with the Institute of Forest and Wildlife Research and Development, Forestry Administration in Cambodia since 2011 and together they have collected a total of 8058 plant specimens from Kampong Chhnang, Kampong Thom, Kampot, Koh Kong, Kratie, Ratanakiri, Mondulukiri and Siem Reap Provinces. Based on these collections, a checklist of the flora of Kampong Chnnang and Kampong Thom (Toyama et al., 2013a) and four volumes of Picture Guides of Forest Trees in Cambodia for the floras of Kampong Chhnang, Kampong Thom, Kratie and Mt. Bokor were published (Toyama et al., 2012, 2013b; Tagane et al., 2015b, 2017). In particular, our understanding of the plant diversity of the Bokor National Park, Kampot Province, southern Cambodia, has been greatly improved. Of the 770 taxa in 110 families that were collected, 24 species ( $3 \%$ of the total flora) were described as new and more than 100 were found to be new country records $(13 \%)$ (Tagane et al., 2017). Rundel \& Middleton (2017) also documented the flora on the Bokor Plateau, listing 359 species, including 22 endemic species.

\section{Laos}

Very few publications treat the plants of Lao PDR alone. The first, Noms vernaculaires de Plantes en Usage au Laos (Vidal, 1959) listed more than 1000 species with their local names and uses. The second, the Checklist of Lao Plant Names (Callaghan, 2004) lists more than 2000 taxa, including more than 300 cultivated and introduced plants. The need to conserve and manage the flora at national level gave the impetus to develop a National Checklist (Newman et al., 2007; Newman, 2018). Newman et al. (2007) cited specimens but did not give vernacular names so Inthakoun \& Delang (2008) published a further checklist in which each scientific name is linked to a vernacular name. Recently, another checklist with scientific and vernacular names has been published (Jin et al., 2016), though neither this, nor that of Inthakoun \& Delang (2008), cite specimens.

Kyushu University, Japan, began botanical expeditions in Laos in 2015 in collaboration with the herbarium of the Faculty of Forestry, National University of Laos (FOF). The collecting effort so far has been in Louang Namtha, Vientiane, 
Bolikhamxai, Champasak and Sekong Provinces. As Laos has the lowest collection density in Southeast Asia, new collection programmes inevitably reveal previously unknown species and new records in Laos. For example, among the 181 plant taxa collected from Nam Kading National Protected Area, Bohlikamxai Province, eight species (4.4\%) were found to be new to science (Souladeth et al., 2017, 2019; Tagane et al., 2018a; Souvannakhoummae et al., 2019; Yang et al., 2018) and 30 species (16.5\%) were found to be new records in Laos (Tagane et al. 2018b). In 2019, Phetlasy Souladeth (FOF) began a two-year project to document the plant diversity of the Bolaven Plateau, Champasak Province, Attapeu Province and Sekong Province, in collaboration with Kagoshima University, Japan, and a similar trend is being found.

The number of species expected to occur in Laos has risen with each new checklist and study. Newman et al. (2007) listed 4850 species, while Jin et al. (2016) list 5200. With each new collecting and taxonomic research programme leading to new species and records amounting to around $20 \%$ of all collections, it is possible that the number of species expected to occur in Laos will reach 6000 species.

\section{Vietnam}

In addition to the works discussed under Cambodia, Laos and Vietnam above, there have been a number of works, starting in the second half of the nineteenth century, on the national flora of Vietnam alone. Pham-Hoang \& Nguyen (1960) published a Flora of southern Vietnam (Cây cỏ miền Nam Việt Nam) which included 1650 vascular species. In the second edition of this work, Pham-Hoang $(1970,1972)$ illustrated 5328 species. Based on the Flore générale de l'Indochine, Pócs (1965) reported 5035 species for northern Vietnam, and Thai $(1970,1978)$ recorded 7004 species for northern Vietnam. Meanwhile, Phan (1970), in a preliminary work, listed only 5609 species for northern Vietnam. In 1984, T.B. Nguyen et al. (1984) published a flora of Vietnam's Central Highlands with 3201 species; this was a result of a five-year inventory by a team of botanists from the Institute of Biology and the University of Ha Noi.

The first national flora came out as An illustrated Flora of Vietnam (Cây cỏ Việt Nam) with about 10,500 species in 3 volumes and 6 parts by Pham-Hoang (19911993). Almost at the same time, a vascular plant synopsis of the Vietnamese flora was published in two volumes, providing species checklists of 58 families of higher plants (Averyanov et al., 1990, 1996). In his phytogeographic study of the Vietnamese flora, Le (1999) provided a checklist of 10,193 species. However, Pham-Hoang (19992000) published a new edition of An illustrated Flora of Vietnam and increased the number of plant species in Vietnam to 11,662. The two editions of the national flora by Pham-Hoang have been, and will continue to be for some time, the most consulted and cited references on Vietnam's flora within Vietnam. Meanwhile, 11,083 vascular plant species were listed in the three volumes of the Checklist of Plant Species of Vietnam (Danh lục các loài thực vật Việt Nam) (Vietnam National University, Ha Noi, 2001; T.B. Nguyen et al., 2003, 2005), including one species of psilotophytes, two species of equisetophytes, 691 species of polypodiophytes (which would now be treated as 694 species of ferns), 53 species of lycopodiophytes, 69 species of gymnosperms and 10,267 species of angiosperms. However, among these are at least 874 introduced 
species and many are possibly synonyms. There have also been attempts to revise particular plant groups such as common plants (Le et al., 1969-1976), forest trees (Vietnam Ministry of Forestry, 1971-1988; Vu, 1996), conifers (D.T.L. Nguyen \& Thomas, 2004; Phan et al., 2013, 2017), dipterocarps (H.N. Nguyen, 2005), ferns (Phan, 2010), orchids (Averyanov 2008, 2010, 2011, 2013; Averyanov \& Averyanova, 2003; T.T. Nguyen, 2001), etc. Ongoing large-scale collecting programmes are being conducted by HN, SGN and VNMN (Thiers, continuously updated) with the support of the Vietnam Academy of Science and Technology.

An ongoing project to compile a national flora of Vietnam has been implemented by the Institute of Ecology and Biological Resources of the Vietnam Academy of Science and Technology since 1996. To date, 21 volumes have been published, providing taxonomic accounts of 3773 species, subspecies \& varieties. Where families have been treated in both the Flora of Vietnam and the Flore du Cambodge, du Laos et du Viêtnam (e.g. Apocynaceae, Solanaceae), the species concepts in the Flora of Vietnam tend to be narrower and hence more species are recognised.

Pham-Hoang (1991-1993, 1999-2000) estimated that the vascular flora of Vietnam would have about 12,000 species. Although several other authors have agreed with this estimate (e.g. Regalado et al., 2005), the floristic diversity of Vietnam would appear to be greater than previously suggested. The Zingiberaceae, for example, included 98 species in Pham-Hoang (2000) and 140 in Q.B. Nguyen (2017) but the number of known species is presently about 200 and will continue to increase (Tran Huu Dang, pers. comm.). In recent years over 50 new species or new country records in many different families have been published from Vietnam every year. At this rate it is almost certain that the final total number of species in Vietnam will exceed PhamHoang's estimated figure.

In addition to these activities, Vietnamese institutions have continued to collaborate with a number of other institutions to research Vietnamese plant diversity. For example, Dalat University has been working with both Kyushu University in Japan and the Singapore Botanic Gardens to explore areas such as Ba Vi National Park (NP), Bidoup-Nui Ba NP, Hoang Lien NP, Hon Ba Nature Reserve, Ngoc Linh NP and Vu Quang NP. These expeditions have led to a field guide (Nagahama et al., 2019) and the description of many new species (e.g. Mitsuyuki et al. 2017; Binh et al., 2018; Ngoc et al., 2018; Dang et al., 2019), with many more awaiting description.

\section{Indonesia}

Indonesia is the largest country in Southeast Asia and the largest archipelagic state in the world, situated between the Asian and Australian continents and between the Indian and Pacific oceans, lying across the equator from $6^{\circ} \mathrm{N}$ to $11^{\circ} \mathrm{S}$ and between $95^{\circ}$ $\mathrm{E}$ and $141^{\circ} \mathrm{E}$. The country extends approximately $5100 \mathrm{~km}$ from east to west, and has a total land area of about 1,919,440 $\mathrm{km}^{2}$ (BIG, 2014). Indonesia has gazetted 13,466 islands from the 17,000 islands of the archipelago, of which about 6000 are inhabited (KPPN/Bappenas, 2016; Irawati \& Widyatmoko, 2019). Due to the size of the country, its tropical climate, and its geography and geology, Indonesia supports a high level of biodiversity and many different types of habitats and ecosystems, comprising a 
mixture of species derived from lineages of Asian or Australian origin. It is one of the world's megadiverse countries (Whitten et al., 1987; Lohman et al., 2011; De Bruyn et al., 2014; Von Rintelen et al., 2017). Physiographically, Sumatra, Borneo, Java and Bali islands are connected to the Sunda Shelf of the Asian continent, while to the east, New Guinea and the Aru islands lie on the Sahul Shelf, as part of the Australian continent. Between these two shelves, the island groups of Nusa Tenggara, Sulawesi, and Maluku have long been separated from the two continental landmasses and have consequently established their own unique plant assemblages (Monk et al., 1997; Irawati \& Widyatmoko, 2019). Indonesia is also one of the Coral Triangle countries possessing the world's greatest diversity of coral reef fishes. The Indonesian islands stretch out on a major fault and are part of the infamous volcanic zone called the Ring of Fire, consisting of more than 400 volcanic mountains of which 100 are active, making the region one of the most changeable geological areas in the world.

Despite occupying only $1.3 \%$ of the world's land surface, Indonesia has approximately $10 \%$ (c. 35,000 species) of the world's flowering plant diversity (based on the recent estimates in Table 1), and of which only 19,232 species have currently been identified and named (KPPN/Bappenas, 2016; Widyatmoko, 2018). Indonesia has 238 species (34\% of the world's total) of dipterocarps, 2197 species of ferns $(21 \%)$, c. 5500 species orchids $(20.5 \%), 477$ species of palms $(20 \%), 159$ species of bamboos $(13 \%)$, and 723 species of lichens $(8 \%)$. Indonesia's palm diversity is the highest in the world, 53\% of which are endemic (Widyatmoko, 2018). Indonesia is also a centre for crop and livestock wild relatives. The main agricultural products are rice, palm oil, tea, coffee, cacao, medicinal plants, spices, and rubber.

Apart from the high level of species richness, many of the species occurring in Indonesia are endemic. Nusa Tenggara (Lesser Sunda Islands), Papua, and Java contain the highest percentages of endemic plants according to KPPN/Bappenas (2016, modified) (Table 5) but, using different geographical concepts not confined to Indonesia, the highest percentages of endemic plants are in New Guinea, Borneo and Sulawesi according to Van Welzen et al. (2005) (Table 6).

The earliest recordings of plants in Indonesia were artistic and commercial. Floral reliefs were carved at the Borobudur temple built in the $8^{\text {th }}$ and $9^{\text {th }}$ centuries in Central Java (Widjaja \& Kartawinata, 2013). During that period and thereafter, what is now Indonesia was an important centre for trade between local and foreign merchants. The first Europeans, Portuguese traders, arrived in the early $16^{\text {th }}$ century and quickly attempted to monopolise the trade in nutmeg, cloves, and cubeb pepper in the Moluccas. They were closely followed by Dutch and English (later British) traders (Ricklefs, 1993). The Dutchman Jan Huyghens van Linschoten, who lived in Goa and Cochin in India from 1583 to 1589, was the first foreign plant explorer to discover a direct navigational route to the Dutch East Indies (now Indonesia), thereby enabling the passage to be opened up to trade. Linschoten collected botanical data and produced a species list and scientific descriptions of various useful species, including spices, sandalwood, agarwood, camphor and benzoin. Dutch explorers were followed by French, Italian, Portuguese, Spanish and Swedish explorers in the Indonesian archipelago until the end of the 16th century (De Wit, 1949). 
Table 5. Number of flowering plant species and the percentage of endemicity for each bioregion in Indonesia.

\begin{tabular}{llll}
\hline Bioregion & $\begin{array}{l}\text { Estimated number } \\
\text { of species }\end{array}$ & $\begin{array}{l}\text { Estimated number } \\
\text { of endemics }\end{array}$ & $\begin{array}{l}\text { Percentage of } \\
\text { endemics }\end{array}$ \\
\hline Sumatra & 8391 & 1891 & 22.5 \\
Java & 6305 & 2906 & 46 \\
Kalimantan & 9956 & 3936 & 39.5 \\
Sulawesi & 5972 & 2225 & 37.3 \\
Nusa Tenggara & 2442 & 1343 & 55 \\
Maluku \& Papua & 9518 & 4380 & 46 \\
\hline
\end{tabular}

Table 6. The number of flowering plant species and the percentage of endemicity for Malesian regions based on an analysis of a sample of 6616 indigenous species published in Flora Malesiana series 1 and the journal Orchid Monographs (Van Welzen et al., 2005)

\begin{tabular}{lccc}
\hline Bioregion & $\begin{array}{c}\text { Estimated number of } \\
\text { species }\end{array}$ & $\begin{array}{c}\text { Estimated } \\
\text { number of } \\
\text { endemics }\end{array}$ & $\begin{array}{c}\text { Percentage of } \\
\text { endemics }\end{array}$ \\
\hline Sumatra & 1854 & 203 & 10.9 \\
Malay Peninsula & 1895 & 261 & 13.8 \\
Borneo & 2436 & 908 & 37.3 \\
Java & 1196 & 56 & 4.7 \\
Philippines & 1651 & 454 & 27.5 \\
Sulawesi & 1065 & 144 & 13.5 \\
Nusa Tenggara & 815 & 42 & 5.2 \\
Maluku & 804 & 71 & 8.8 \\
New Guinea & 2613 & 1419 & 54.03 \\
\hline
\end{tabular}


Linschoten stimulated Dutch merchants to develop the Vereenigde OostIndische Compagnie (VOC) in 1602 to explore the East for commercially exploitable plants and other natural resources (De Wit, 1949). Georg Eberhard Rumpf (Rumphius) joined the VOC in 1652, arrived in Ambon in 1653, conducted research, studied the flora and fauna of Ambon and the vicinity, and wrote an account of approximately 1300 plant species in his Herbarium Amboinense.

European explorers who came specifically to study tropical botany in Indonesia included a student of Linnaeus, Carl Pehr Thunberg (in 1777), and also Claes Frederic Hornstedt (in 1783-1784), Francisco de Norona (in 1787), Louis Auguste Deschamps (in 1793), and Louis Theodore Leschenault de la Tour (in 1802) (Van Steenis \& Van Steenis-Kruseman, 1953).

Realising that the Dutch East Indies were rich in natural resources, in $1815 \mathrm{King}$ Willem I instructed Reinwardt to explore the commercial potential of plants from the region. On May $18^{\text {th }}, 1817$, Bogor Botanic Gardens was established to support the King's mission and Reinwardt was appointed as the Director (Goss, 2011; Widjaja \& Kartawinata, 2013; Ariati \& Widyatmoko, 2019). Due to the enormous value of the spice trade, botanists were highly influential in the Dutch East Indies in the $19^{\text {th }}$ century.

Blume, the successor of Reinwardt, attempted to write a Flora of the Netherlands Indies and a Flora of Java, followed by Zollinger, Miquel, Koorders and Docters van Leeuwen (De Wit, 1949). Each of them published valuable works for the region but none ever produced a comprehensive reference. Later, the Flora of Java was completed by Backer \& Posthumus (1939) and Backer \& Bakhuizen van den Brink (1963-1968).

The British naturalist Alfred Russel Wallace explored Indonesian plant diversity between 1854 and 1862. Wallace demonstrated a dividing line, aptly known as the Wallace Line, lying between the distribution of Indonesia's Asian and Australasian species (Severin, 1997; Goss, 2011). The line is situated north-south along the edge of the Sunda Shelf, between Borneo and Sulawesi, and southwards between Lombok and Bali. Broadly, the flora to the west of the line is more Asian, while from Lombok eastwards it is more Australasian. Wallace is celebrated for his contributions to the theory of speciation through natural selection but he also published a seminal work on the biodiversity of the region (Wallace, 1869). Wallace scientifically chronicled the natural world of Indonesia and described numerous species unique to the area, developing a long-lasting contribution to the ecological understanding of the region (Goss, 2011). The region of islands between the Wallace Line and New Guinea is now called Wallacea (Severin, 1997).

Heyne (1927) published the book De Nuttige Planten van Nederlandsch-Indie (Useful Plants of the Dutch East Indies), later republished as De Nuttige Planten van Indonesie (Heyne, 1950). The book covered 5006 species, consisting of 1259 species of timber, 1050 species of medicinal plants, 984 species of food plants, 520 species producing oil, resin, dyes and other natural chemical substances, 328 species of animal feed, and 885 species of multiple uses (Widjaja \& Kartawinata, 2013). The book was translated into Indonesian by the Forestry Research and Development Agency (Heyne, 1987). PROSEA (Plant Resources of South East Asia), hosted by the 
Herbarium Bogoriense of the Indonesian Institute of Sciences (LIPI) and funded by the Government of the Netherlands, has published 19 volumes on the economic plants of Southeast Asia, including pulses, edible fruits and nuts, dye and tannin-producing plants, forages, timber trees, rattans, bamboos, vegetables, carbohydrate producing plants, cereals, auxiliary plants in agriculture and forestry, medicinal and poisonous plants, spices, vegetable oils and fats, lower plants, stimulants, fibre plants, exudate producing plants, and essential-oil plants.

Plant conservation is a priority of the research staff of the Bogor Botanic Gardens of the Indonesian Institute of Sciences (LIPI). In the book Spesies Prioritas untuk Konservasi Tumbuhan Indonesia (Priority Species for Conserving Indonesian Plants) (Risna et al., 2010) 180 Indonesian threatened plant species were assessed by specialists working on the target taxa (Arecaceae, Cyatheaceae, Nepenthaceae, and Orchidaceae). Seventeen criteria divided into five themes were used to assess and prioritise each species, comprising uniqueness, threats, vulnerability and endangerment, propagation potential, and use value. This resulted in three categories of priority, of which 100 species were considered to be highly threatened and require immediate intervention or conservation action.

Other recent initiatives include the book entitled 3500 Plant Species of the Botanic Gardens of Indonesia (Sukarya, 2013) based on the very extensive plant collections cultivated in the four national botanic gardens of Indonesia (Bogor, Cibodas, Purwodadi, and Bali), covering approximately half of the total existing-living collections of the four gardens, and the book Eksplorasi Flora: 25 Tahun Menjelajah Rimba Nusantara (Flora Exploration: 25 Years Exploring Indonesian Forests) (Hidayat et al., 2017), which marked the bicentenary of Bogor Botanic Gardens and covered a total of 1173 plant species collected from 200 different locations throughout the Indonesian archipelago. The explorations were conducted from 1992 to 2017 and involved more than 100 researchers and explorers and 200 supporting technical workers.

Van Balgooy \& Widjaja (2014) published a Provisional Checklist of the Flora of Bali. The checklist comprises a total of 1338 species of spermatophytes, 165 species of pteridophytes, 71 species of bryophytes and hepatics, and 75 species of fungi. The spermatophytes consist of 152 families (with 748 genera), of which the Poaceae (consisting of 162 species), Orchidaceae (113 species), and Fabaceae (80 species) are the largest families on the island. Compared to Java, the flora of Bali is much less well explored, despite being a famous tourist destination. During the $9^{\text {th }}$ International Flora Malesiana Symposium in Bogor in 2013, Herbarium Bogoriense announced that the Lesser Sunda Islands (including Bali) would be a priority region to be studied and would include a Flora of Bali (Van Balgooy \& Widjaja, 2014). However, the Flora of Bali is not yet complete. Notable earlier reports on the botany of the island were made by Rensch (1930), De Voogd (1937a, 1937b, 1940), and Van Steenis (1950). Cornelis N. A. de Voogd was the most prominent collector of and publisher on Balinese plants, while Van Steenis provided a foundation for a comprehensive study on the flora of the island following his extensive collecting activities (Van Balgooy \& Widjaja, 2014). 
The island of New Guinea is divided between Indonesian New Guinea, comprising of the provinces of West Papua and Papua, and the independent nation of Papua New Guinea (see below). The Indonesian part of New Guinea includes Malesia's highest peak, Mt Jaya, rising to $4884 \mathrm{~m}$. This portion of New Guinea has been explored historically by several botanists, e.g., collections by L.S. Gibbs in the Arfaks (Gibbs, 1917) and L.J. Brass during the $4^{\text {th }}$ Archbold Expedition (Brass, 1941), but Indonesian New Guinea has no dedicated Flora or Florula project (such as that of Papua New Guinea). More recent published floristic data are few, but there is the comprehensive island-wide Alpine Flora by Van Royen (1979a, 1979b, 1982, 1983) and a recent checklist by Mangen (1993) included in an ecological study of Mt Trikora. However, the region is the subject of continued effort by the Royal Botanic Gardens, Kew in collaboration with the West Papua Provincial Government, and the University of Papua (UNIPA). RBG, Kew has undertaken several large expedition programmes in the region, especially in the Arfak Mountains and the Mt Jaya area. The latter work resulted in a checklist of the subalpine and alpine areas of New Guinea (Johns et al., 2006) and an assessment of the conservation threats to the upland flora (Utteridge $\&$ Edwards, 2009). The region still has large tracts of lowland rainforest and will be important for mitigating climate change. To better understand future planning in the region it has been selected as a Tropical Important Plant Area candidate to enable informed regional-scale conservation prioritisation (Darbyshire et al., 2017). An island-wide expert-verified species checklist has been prepared at Kew, drawing on taxonomic expertise across the globe, and has been submitted for publication (CamaraLeret, pers. comm.).

\section{Brunei}

Brunei may be small (some $5765 \mathrm{~km}^{2}$ or less than $1 \%$ of Borneo, the third largest island in the world) but it is important for several reasons. It is part of the Northwest Borneo hotspot (Ashton et al., 2003) where species diversity is spectacular but much land-use alteration has taken place in the past century, yet as a Bornean territory it alone retains some $70 \%$ of its land area under forest cover, including some of the best examples anywhere in the island or the region.

The size of the Brunei flora has been estimated as c. 5000 species of seed plants, including perhaps some 2000 species of trees (Wong \& Kamariah, 1999). Because of the relatively short history of botanical exploration in Brunei, much is undocumented and more exploration and collecting is necessary.

Documentation of its flora can be said to have begun systematically after Brunei became a British Protectorate (before oil was discovered in the 1920s), when forestry officials from the Federated Malay States in the Malay Peninsula were sent to investigate its resources. After a brief visit in 1914, Deputy Conservator of Forests Cornelius Hummel confirmed "rumours for a long time of the existence of a magnificent forest in Brunei” (Durant, 1933a). But only in 1933 was a Forest Department formed, establishing a first phase of forest management with a forest enactment and rules and the constitution of forest reserves (occupying $42 \%$ of Brunei's land area in the late 1950s) (Durant, 1933b). B.E. Smythies (1956), the well-known forester, ornithologist 
and botanist, prepared a 10-year forestry development plan that also emphasised a more comprehensive study of the tree resources ("this corner of Borneo is probably the richest in the world for dipterocarps") (Wong et al., 2015). Peter Ashton, Brunei's first forest botanist, arrived in 1957 and soon produced the first botanical manual for the identification of dipterocarps (the dominant big trees of the lowland forests and the mainstay of the timber industry) (Ashton, 1964).

In the late 1930s, botanical specimens from Brunei were sent for identification to the Forest Research Institute at Kepong [Malaya, now Peninsular Malaysia]. In 1949, administration of Brunei forestry was transferred to Sarawak because of a shortage of staff until Bill Smythies became State Forest Officer in Brunei in 1952. Smythies was keen on the botany of trees and pitcher plants, and continued plant collecting. It was Peter Ashton, with forester Hasan bin Pukul and others, who established Brunei's herbarium. Hasan bin Pukul \& Ashton (1965) wrote the first Checklist of Brunei Trees in 1965. A hiatus in botanical research followed Ashton's departure from Brunei in the 1960s, until 1987 when forest botany was revived with the appointment of K.M. Wong as forest botanist. This was during Haji Mohd Yassin Ampuan Salleh's tenure as Director, very much the moment of botanical revival, when in 1989 the Brunei Forestry Department and the Royal Botanic Gardens Kew formed a Memorandum of Understanding that began a period of intensive collaborative collecting. This effort resulted in A Checklist of the Flowering Plants and Gymnosperms of Brunei Darussalam (Coode et al., 1996a, b). The Checklist possibly covered some 3500 recognisable species. After the Checklist project, Brunei herbarium staff members continued regular collecting, building up even more documentation, including plant species that had not been accounted for earlier.

In 2013, the Brunei Government, represented by the Forestry Department, began a close collaboration with the National Parks Board, Singapore, with the Singapore Botanic Gardens as a key partner in an effort to further botanical exploration and specialist studies of the Brunei flora. This was the third important phase of organised studies into the plant diversity of Brunei, after Ashton and the Kew project (Joffre et al., 2015). These two periods of international collaboration are highly significant and have helped circulate a large volume of Brunei material among the world's key herbaria, also helping to build interest among worldwide specialists of the Southeast Asian region (Wong et al., 2015).

From a collection of 14,000 in the late 1980 s, the Brunei National Herbarium (BRUN) grew to some 40,000 in 2015 , around a quarter century later. With the biological highlights, His Majesty The Sultan in 1991 declared 46,210 hectares of prime forest as the Ulu Temburong National Park, Brunei's very first (Wong, 1988). Borneo's forest cover declined from $71 \%$ of the island's area (mid-1980s) to 54\% (2000) (Bryan et al., 2013), so that Brunei's efforts are laudable. In 2014, the Minister of Industry and Primary Resources began to phase out logging in all Forest Reserves (Brunei Times, 2014). Brunei's immense species richness requires much more exploration and documentation and would greatly benefit from further regional collaboration (Wong, 2015, 2016, 2017). 


\section{Philippines}

Floristic research in the Philippines was reviewed twice by Merrill $(1903,1926)$ and most recently by Tan \& Rojo (1989). The earliest synthesis of floristic research in the Philippines was Blanco's Flora de Filipinas, published in three editions (Blanco, $1837,1845,1877-1883)$. Between the various editions, large numbers of new genera and species were described. The third edition (Blanco, 1877-1883) was published in four volumes of text and two volumes of plates and included various additional works, amongst them an enumeration of all plants then known from the Philippines compiled from various sources. Noting the lack of herbarium material to clarify Blanco's species concepts (but see Veldkamp, 1989) and that there was a lot of inaccurate data, Merrill (1918) set out to review all of Blanco's names, and the work overall. Despite its shortcomings, Merrill (1918) considered Flora de Filipinas to be "a remarkable book on some respects" as Blanco worked under great disadvantages with only a handful of reference books and far away from the large herbaria and botanical libraries of Europe.

The arrival of Sebastian Vidal in the Philippines in 1871 as Inspector General of the Forestry Bureau led to "a distinct renaissance in local botany" (Merrill, 1926), particularly through a number of important publications (Vidal, 1883, 1885, 1886).

Elmer Drew Merrill (1876-1956) arrived in the Philippines in May 1902 after being appointed as botanist at the Bureau of Agriculture. Merrill was the single-most influential figure in Philippine botany and laid the foundation for a botanical inventory of the islands. In all, he described over 3000 new species of plants (including plants from Polynesia, China, Moluccas, and Borneo). More than 275,000 specimens were accumulated under his administration, with duplicate specimens distributed to several herbaria and individuals overseas. His four-volume An Enumeration of Philippine Flowering Plants (Merrill, 1923-1926) included 8120 species of flowering plants, 11,200 synonyms, and 13,600 vernacular names. He also noted that there were 1000 species of ferns and lycophytes and 3000 species of algae, lichens, mosses, and hepatics (Merrill, 1926). This was a significant increase from only about 2500 described species at the close of the $19^{\text {th }}$ century. Merrill (1912) also earlier published the 490-page $A$ Flora of Manila covering more than a thousand species. An Enumeration was, perhaps, the closest to Merrill's ultimate goal of "publishing a general descriptive flora of the Philippines" (Merrill, 1953).

In July 1903, all botanical work was transferred to the Bureau of Government Laboratories, later becoming the Bureau of Science under his supervision. Botanical explorations were undertaken by employees of the Bureau of Forestry and the Bureau of Science leading to many publications in local and international journals. Many specialists worked on particular groups of plants, e.g. V.F. Brotherus (mosses), H. Christ and E.B. Copeland (ferns and fern allies), O. Ames (orchids), O. Beccari (palms), U. Martelli (pandans), among many others. Of these, Copeland (1873-1964) accumulated about 25,000 mounted specimens, including 600 types. He published the Fern Flora of the Philippines in three volumes (Copeland 1958, 1960a, 1960b) accounting for 17 families, 150 genera, and 943 species.

A.D.E. Elmer (1870-1942) made the largest single collection of Philippine plants by any individual working as a private collector. His specimens were widely 
distributed to botanical institutions throughout the world. He described over 1500 new species, mostly in his Leaflets of Philippine Botany published between 1906 and 1939.

Later significant contributions to our understanding of plant diversity in the Philippines include Pancho (1983), Newman et al. (1996), Rojo \& Aragones (1997), Primavera et al. (2004), Pancho \& Gruezo (2006), McPherson \& Amoroso (2011), Primavera \& Sadaba (2012), Amoroso et al. (2016), and Fernando et al. (2017).

The Philippine Flora Project started as a collaborative activity in 1990 between Dr Domingo A. Madulid of the Philippine National Herbarium and Dr S.H. Sohmer of the Bishop Museum in Honolulu, Hawaii and later the Botanical Research Institute of Texas in Fort Worth. In part, as a response to the continuing decline of forest areas, the flora project was designed to accomplish three objectives (Sohmer, 1996): (i) document the remaining flora as quickly as possible through a country-wide collecting effort; (ii) strengthen the botanical infrastructure of the country by helping to upgrade the facilities at the national herbarium; and (iii) produce a new comprehensive account of the flora of the Philippines that will provide a contemporary understanding of the native and naturalised plants of the archipelago. The activities of the Flora project were intended to be divided into three phases, viz. plant inventory, collections management, and writing and documentation (research and editing). The final Flora product was anticipated to be a set of eight volumes if illustrated, or five to six if not. Following a workshop in Fort Worth in 1994 it was also agreed, in addition to the printed flora, to develop a "database of all the taxonomic and floristic information available" for Philippine plants (Sohmer, 1996).

The plant inventory component, formally referred to as the Philippine Plant Inventory (PPI), was inaugurated in January 1991 with three weeks of field work on Palawan Island leading to the collection of more than 4200 specimens (Stone, 1991). During 1991-1992 about 9031 collections were made (Sohmer, 1996). Funding for the PPI was provided by the US National Science Foundation and was secured until 1997. The main sets of the collections are housed at PNH and BISH, and later BRIT, with duplicates to K, L, US, and other herbaria (Stone, 1991). Unfortunately, the crucial phase of actually writing the Flora has failed to materialise.

In addition to activities under the PPI programme, there have also been large collaborative collecting expeditions to Palawan in 1984 (Podzorski, 1985), Luzon, Mindoro, Panay, Palawan, and the Visayas from 1986 until 1991 (Soejarto 1989; Soejarto et al., 1996) and recent joint USA/Philippines collecting efforts (Gosliner \& Burke, 2013; Tan \& Shevock, 2014).

There are at least 15, mostly small, university herbaria registered with the Index Herbariorum with a total of more than 465,000 specimens (Thiers, continuously updated). The Philippine National Herbarium (PNH) has the largest collection of over 200,000 specimens, although there were over 500,000 around 1940. The herbarium and the bulk of these collections, however, were destroyed during the Second World War. The herbarium was rebuilt in 1946. This has been a recurring problem in the Philippines as Vidal's herbarium and library in the Forestry Bureau was destroyed by fire in September 1897 and then later also the smaller collection by Naves and Fernandez-Villar in February 1899. 
The online 'Co's Digital Flora of the Philippines' is an annotated checklist of the vascular flora of the Philippines edited by Pelser et al. (2011 onwards) (www.philippineplants.org) based on the unpublished checklist of Leonardo L. Co following Merrill's Enumeration (Barcelona et al., 2013). The checklist is arranged alphabetically by family and includes currently accepted names, types, synonyms, and geographic distributions. It is linked to PhytoImages (www.phytoimages.com) with multiple photographs (when available). The site is regularly updated by the editors based on recent taxonomic revisions and monographs. In 2013 the checklist contained 10,107 species, 2001 genera, and 260 families of native and naturalised pteridophytes, gymnosperms, and angiosperms with about $28 \%$ of the species illustrated with colour images (Barcelona et al., 2013) and has continued to be populated with additional taxa and images since then. The website is particularly useful to keep up with name changes and new taxa of Philippine plants.

As earlier noted by Tan \& Rojo (1989) and Soejarto et al. (1996) among others, there continues to be a problem in PNH and elsewhere in the Philippines of an insufficient number of qualified taxonomic botanists to undertake floristic treatments and taxonomic revisions.

\section{Papua New Guinea}

Although New Guinea is recognised as one of the floristically richest regions in the world (Conn, 1994), only rough estimates of the number of plants species are available. This is largely due to insufficient plant collecting in much of the country and a lack of publications on this region's flora. Conn (1994) provided a far more detailed analysis of the plant collections from New Guinea, up until 1994, than had been undertaken prior to then or since. Within New Guinea, the number of collections range from more than 225 collections $/ 100 \mathrm{~km}^{2}$ in areas like the Aseki-Bulolo-Wau region (Papua New Guinea) to fewer than 25 collections $/ 100 \mathrm{~km}^{2}$ throughout much of New Guinea (Conn, 1994, see Figs 3 \& 4). Conn concluded that the density of collections throughout much of New Guinea is fewer than 25 collections/100 km² (Conn, 1994) even though the overall collection density for the island of New Guinea has been estimated to be much higher (see Table 2). He concluded that an understanding of the distribution, habitat preferences, morphological and genetic variability, conservation status, or biology of taxa cannot be achieved without a significant increase in collection density within Papua New Guinea (Conn, 1994). Mapping the distribution of tree species has proven to be problematic (Conn \& Damas, 2019) because of the low density of collections. Even relatively widespread species are frequently under-represented in herbaria. The second reason why the understanding of the flora of this region is inadequate is because there is no comprehensive account of the flora of New Guinea. Although there have been significant scientific publications on plants of this region, such as through the Flora Malesiana series, few publications that focus on the New Guinean flora have been produced. Although there have been some important publications on the flora of Papua New Guinea, these have not provided a comprehensive documentation of the flora. The most comprehensive have been on forest trees (Van Royen, 1964; Coode, 1969), grasses (Henty, 1969), legumes (Verdcourt, 1979) and alpine plants 
(Van Royen, 1979a, 1979b, 1982, 1983). In Papua New Guinea, an attempt was made to publish a flora account but only three volumes appeared (Womersley, 1978; Henty, 1981; Conn, 1995). This series has been suspended, largely because the Papua New Guinea National Herbarium (LAE) is unable to resource such a semi-monographic style flora publication (Conn, 1994).

The PNGtrees project (Conn \& Damas, 2006+) was initiated in 2003 as an online collaborative research programme between the National Herbarium of New South Wales (NSW) and the Papua New Guinea National Herbarium (LAE), since it was recognised that one of the major concerns facing the people of Papua New Guinea was their lack of capacity to document the rich floral diversity of their country. The aim of the project was to develop a simple, structured method for documenting the flora of Papua New Guinea, with the first phase focusing on the economically important and common tree species. The guiding principle was that this project should not only document the tree flora of this nation, but it should train future Papua New Guinean scientists to be experts on the taxonomy of the flora of their region. If the resources available to these scientists were likely to remain limited, at least in the short- to medium-term, then the documentation process had to be achieved with minimal technical support and with few personnel (Conn \& Damas, 2006+). Since LAE currently has limited computational capability, the system needed to be simple, being both easy to operate and manage, without compromising the quality of the data. The details of the format and scope of this project are provided by Conn \& Damas (2006+). The Trees of Papua New Guinea publication (Conn \& Damas, 2019) provides a comprehensive treatment of 668 species of trees (Volume 1: 257 species; Vol. 2: 246 species; Vol. 3: 165 species) that is designed to assist in the identification of the trees of Papua New Guinea. One of the outcomes of this electronic collaboration and printed publication has been the strong awareness that the circumscription of many species and infraspecific taxa, even some genera, do not adequately describe the morphological variation observed. Although Joppa et al. (2011: 13175) concluded that "New Guinea's catalog of plant species [is] nearly complete", this conclusion was not supported by the PNGtrees project.

A multipurpose National Forest Inventory (NFI) project, funded by the European Union and managed by FAO, was initiated in 2011 (FAO, 2018). The focus of the NFI was on sampling a full suite of biological and physical parameters to provide the technical data and information required for REDD++ for Papua New Guinea. The UN-REDD PNG National Programme and Papua New Guinea Forest Authority (PNGFA) developed the methodologies and all NFI components, including tree inventory, non-tree plant biodiversity, ornithology, entomology and soil types. An additional collaboration between PNGFA and the Japan International Corporation Agency concentrated on the reclassification of the forest types within Papua New Guinea using Collect Earth protocols (https://collect.earth/).

The NFI project was officially launched in March 2016, by the Prime Minister of Papua New Guinea, and the field assessments commenced in May 2017 and have continued in various parts of PNG to date, with external funding officially ending in August 2019. Herbarium Vouchers have been collected for all plants recorded in each 
plot. These vouchers have been, and will be, processed, and the field identifications verified at LAE. Fertile collections are incorporated into the main LAE collection whilst sterile collections are stored in the NFI laboratory (in Lae). So far, the project has generated about 12,810 botanical specimens (representing c. 7,680 collections per year). This represents a major collection event in the history of botany in Papua New Guinea. For comparison, the NGF collection series (from 1944 until 1977) was almost 1520 collections per year, whereas the LAE series (from 1970 until 1982) was about 2300 collections per annum (Conn, 1994). The number of species recorded in the NFI is currently not known. The NFI project has also enabled the training of future generations of botanists.

The scope and restricted timeframe of this NFI project has been a major challenge. Unfortunately, documentation of the flora, especially not the tree component, was not incorporated and is a major lost opportunity. Also unfortunately, no field-based data were incorporated into the PNGtrees project. Nevertheless, the results of the NFI project and the botanical collections obtained will be available for researchers to gain a better understanding of the plant diversity of Papua New Guinea.

\section{Conclusions}

Southeast Asia is a region of high plant diversity but our knowledge of this diversity is only as good as the data we have available from field work and specimens and from the extent to which these specimens have been incorporated into taxonomic studies. From what we know, however, we disagree with recent suggestions that the Asian tropics have relatively few new species to be described. The widely differing collection densities between and within countries, as well as large differences in the number of narrowly endemic species between plant families, can have marked effects on our understanding of overall plant diversity which, consequently, may have profound effects on regional and national conservation policies. National and transnational Flora projects are essential to set benchmark data and to give anyone who wants or needs to do so the ability to identify plants. Collecting and distributing is essential to ensure that Flora projects include as much as possible of the plant diversity in the area covered, as is the taxonomic study necessary to ensure that the collections are properly utilised to form a stable classification. That so many Flora projects in Southeast Asia are proceeding at too slow a pace impedes our ability to better understand plant diversity across the region. More resources and more international collaboration are needed to overcome these hurdles.

DEDICATION AND ACKNOWLEDGEMENTS. We dedicate this paper to David Mabberley for his contributions to Southeast Asia's Flora projects and, in particular, to his long and tireless support for Flora Malesiana. We thank Niels Raes (L) and Peter Wilkie (E) for discussions on earlier drafts of this paper. We also thank Heather Lindon (K) of the International Plant Names Index for her assistance with the data on new species from Southeast Asian countries. 


\section{References}

Amoroso, V.B., Chen, C.W., Coritico, F.P., Lu, P.F., Alcala, E.L. \& Chiou, W.L. (2016). Guide to Lycophytes and Ferns of Balinsasayao, Negros, the Philippines. Taiwan Pingtung: KBCC Press.

Anderson, B.M. \& Middleton, D.J. (2013). ARevision of Rhynchotechum Blume (Gesneriaceae). Edinburgh J. Bot. 70: 121-176.

Anderson, J.A.R. (1980). A Checklist of the trees of Sarawak. Sarawak: Forest Department.

Argent, G., Lamb, A. \& Phillipps, A. (2007). The Rhododendron of Sabah, Malaysian Borneo. Kota Kinabalu: Natural History Publications (Borneo).

Ariati, S.R. \& Widyatmoko, D. (2019). Botanic Garden Profile: Bogor Botanic Gardens. Sibbaldia 17: 11-28.

Ashton, P.S. (1964). A Manual of the Dipterocarp Trees of Brunei State. Oxford: Oxford University Press.

Ashton, P.S. (1988). Manual of the non-dipterocarp trees of Sarawak, vol. 2. Kuching: Dewan Bahasa dan Pustaka for Forest Department Sarawak.

Ashton, P.S., Kamariah, A.S. \& Idris, M.S. (eds) (2003). A Field Guide to the Forest Trees of Brunei Darussalam and the Northwest Borneo Hotspot, vol. 1. Brunei: Universiti Brunei Darussalam.

Aubréville, A. (1960). Introduction to fascicle 1 (Sabiaceae). In: Flore du Cambodge, du Laos et du Vietnam, pp. 7-9. Paris: Muséum national d'histoire naturelle.

Averyanov, L.V. (2008). The orchids of Vietnam. Illustrated survey. Part 1. Subfamily Apostasioideae, Cypripedioideae and Spiranthoideae. Turczaninowia 11(1): 5-168.

Averyanov, L.V. (2010). The orchids of Vietnam. Illustrated survey. Part 2. Subfamily Orchidoideae. Turczaninowia 13(2): 5-98.

Averyanov, L.V. (2011). The orchids of Vietnam. Illustrated survey. Part 3. Subfamily Epidendroideae (primitive tribes - Neottieae, Vanilleae, Gastrodieae, Nervilieae). Turczaninowia 14(2): 15-100.

Averyanov, L.V. (2013). The orchids of Vietnam. Illustrated survey. Part 4. Subfamily Epidendroideae (tribes Arethuseae and Malaxideae). Turczaninowia 16(1): 5-163.

Averyanov, L. \& Averyanova, A.L. (2003). Updated Checklist of the Orchids of Vietnam. Hanoi: Vietnam National University Publishing House.

Averyanov, L.V., Nguyen, T.B., Nguyen, T.H., Nguyen, T.Q., Phan K.L., Tzvelev, N.N., Duong, D.H., Samutina, M.L. \& Vinogradov, O.I. (1990). Vascular plants synopsis of Vietnamese flora, vol. 1. Nauka, Leningrad. [In Russian]

Averyanov, L.V., Nguyen, T.B., Nguyen, T.H., Phan, K.L., Serov, V.P. \& Akimova, G.A. (eds) (1996). Vascular plants synopsis of Vietnamese flora, vol. 2. World and Family, St. Petersburg. [In Russian]

Backer, C.A. \& Bakhuizen van den Brink, Jr. R.C. (1963-1968). Flora of Java, vols 1-3. Groningen: Walters and Noordhoff.

Backer, C.A. \& Posthumus, O. (1939). Varenflora voor Java. Buitenzorg: Lands Plantentuin.

Van Balgooy, M.M.J. \& Widjaja, E.A. (2014). Flora of Bali: A Provisional Checklist. Reinwardtia 14(1): 219-221.

Barcelona, J.F., Nickrent, D.L., LaFrankie, J.V., Callado, J.R.C. \& Pelser, P.B. (2013). Co's digital flora of the Philippines: plant identification and conservation through cybertaxonomy. Philippine J. Sci. 142 (Special Issue): 57-67.

Beaman, J.H. \& Anderson, C. (2004). The Plants of Mount Kinabalu 5. Dicotyledon Families Magnoliaceae to Winteraceae. Kota Kinabalu: Natural History Publications (Borneo) in association with Royal Botanic Gardens, Kew. 
Beaman, J.H. \& Beaman, R.S. (1998). The Plants of Mount Kinabalu 3. Gymnosperm and Non-Orchid Monocotyledons. Kota Kinabalu: Natural History Publications (Borneo) in association with Royal Botanic Gardens, Kew.

Beaman, T.E., Wood, J.J., Beaman, R.S. \& Beaman, J.H. (2001). Orchids of Borneo. Kota Kinabalu: Natural History Publications (Borneo) in association with Royal Botanic Gardens, Kew.

Bebber, D.P., Carine, M.A., Wood, J.R.I., Wortley, A.H., Harris, D.J., Prance, G.T., Davidse, G., Paige, J., Pennington, T.D., Robson, N.K.B. \& Scotland, R.W. (2010). Herbaria are a major frontier for species discovery. Proc. Nat. Acad. Sci. U.S.A. 107: 22169-22171.

BIG (Badan Informasi Geospasial/Geospatial Information Agency) (2014). Laporan Tahunan Pusat Pemetaan Kelautan dan Lingkungan Pantai. Bogor: Badan Informasi Geospasial.

Binh, H.T., Ngoc, N.V., Tagane, S., Toyama, H., Mase, K., Mitsuyuki, C., Suyama, Y. \& Yahara T. (2018). A taxonomic study of Quercus langbianensis complex based on morphology and DNA barcodes of classic and next generation sequences. PhytoKeys 95: 37-70.

Biswas, K. (1943). Systematic and taxonomic studies on the Flora of India and Burma. Proceedings of the 13th Indian Science Congress, Calcutta 1943, part 2. Presidential Address. Indian Science Congress Association, Calcutta.

Blanco, M. (1837). Flora de Filipinas, ed. 1. Manila.

Blanco, M. (1845). Flora de Filipinas, ed. 2. Manila.

Blanco, M. (1877-1883). Flora de Filipinas, ed. 3, 4 vols text, 2 vols plates. Manila.

Brandis, D. (1906). Indian trees: an account of trees, shrubs, woody climbers, bamboos, and palms indigenous or commonly cultivated in the British Indian empire. London: A. Constable.

Bransgrove, K. \& Middleton, D.J. (2015). A revision of Epithema (Gesneriaceae). Gard. Bull. Singapore 67: 159-229.

Brass, L.J. (1941). The 1938-39 expedition to the Snow Mountains, Netherlands New Guinea. J. Arnold. Arbor. 22: 271-342.

Browne, F.G. (1955). Forest trees of Sarawak and Brunei. Sarawak: Government Press.

Brunei Times (2014). Logging no longer allowed in forest reserves. 23 March 2014, p. A3.

Bryan, J.E., Shearman, P.L., Asner, G.P., Knapp, D.E., Aoro, G. \& Lokes, B. (2013). Extreme differences in forest degradation in Borneo: Comparing practices in Sarawak, Sabah, and Brunei. PLOS One 8(7): e69679.

Burgess, P.F. (1966). Timbers of Sabah. Sabah Forest Records No 6. Forest Department, Sabah. Callaghan, M. (2004). Checklist of Lao Plant Names. Vientiane.

Campbell, D.G. \& Hammond, H.D. (1989). Floristic inventory of tropical countries: the status of plant systematics, collections, and vegetation, plus recommendations for the future. New York Botanical Garden.

Cantley, N. (1884). Report on the Forests of the Straits Settlements. Singapore: Singapore and Straits Printing Office.

Chayamarit, K. \& Puff, C. (2006). Plants of Khao Yai National Park. Bangkok: National Park, Wildlife and Plant Conservation Department.

Chayamarit, K. \& Puff, C. (2007a). Plants of Doi Inthanon National Park. Bangkok: National Park, Wildlife and Plant Conservation Department.

Chayamarit, K. \& Puff, C. (2007b). Plants of Kaeng Krachan National Park. Bangkok: National Park, Wildlife and Plant Conservation Department.

Chen, Y.-Y., Satake, A., Sun, I-F., Kosugi, Y., Tani, M., Numata, S., Hubbell, S.P., Fletcher, C., Supardi, M.N.N. \& Wright, S.J. (2017). Species-specific flowering cues among general flowering Shorea species at the Pasoh Research Forest, Malaysia. J. Ecol. 106: 586-598. 
Chong, K.Y., Tan, H.T.W. \& Corlett, R.T. (2009). A Checklist of the Total Vascular Plant Flora of Singapore, Native, Naturalised and Cultivated Species. Raffles Museum of Biodiversity Research, Singapore.

Clarke, C.C. (1997). Nepenthes of Borneo. Kota Kinabalu: Natural History Publications and Science and Technology Unit, Sabah.

Cockburn, P.F. (1976). Trees of Sabah. Sabah Forest Records No 10, vol. 1. Forest Department Sabah, Sandakan.

Cockburn, P.F. (1980). Trees of Sabah. Sabah Forest Records No 10, vol. 2. Forest Department Sabah, Sandakan.

Conn, B.J. (1994). Documentation of the Flora of New Guinea. In: C.-I Peng \& C.H. Chow (eds) Biodiversity and Terrestrial Ecosystems. Academia Sinica Monograph Series 14, pp. 123-156.

Conn, B.J. (ed.) (1995). Handbooks of the Flora of Papua New Guinea, vol. 3. Melbourne University Press, Carlton.

Conn, B.J. \& Damas, K.Q. (2006+). Guide to Trees of Papua New Guinea. http://www. pngplants.org/PNGtrees. Accessed 04.2019.

Conn, B.J. \& Damas, K.Q. (2019). Trees of Papua New Guinea, vols 1-3. Xlibris.

Coode M.J.E. (1969). Manual of the Forest Trees of Papua New Guinea, part 1, rev. issue, Combretaceae. Lae: Division of Botany.

Coode, M.J.E., Dransfield, J., \& Kirkup, D.W. (1996a). Brunei and biodiversity-The KewBrunei checklist project. In: Edwards, D.S., Booth, W.E. \& Choy, S.C. (eds) Tropical Rain Forest Research-Current Issues. Dordrecht: Kluwer Academic Press.

Coode, M.J.E., Dransfield, J., Forman, L.L., Kirkup, D.W. \& Idris, M.S. (1996b). A Checklist of the Flowering Plants and Gymnosperms of Brunei Darussalam. Brunei: Ministry of Industry and Primary Resources.

Copeland, E.B. (1958). Fern Flora of the Philippines, vol. 1, pp. 1-191. Manila: Bureau of Printing.

Copeland, E.B. (1960a). Fern Flora of the Philippines, vol. 2, pp. 193-376. Manila: Bureau of Printing.

Copeland, E.B. (1960b). Fern Flora of the Philippine, vol. 3, pp. 377-557. Manila: Bureau of Printing.

Corlett, R.T. \& Primack, R.B. (2011). Tropical Rain Forests: An Ecological and Biogeographical Comparison, ed. 2. Chichester: Wiley-Blackwell.

Cowan, J.M. (1954). Some information on the Menzies and the Jack collections in the herbarium of the Royal Botanic Garden, Edinburgh. Notes Roy. Bot. Gard. Edinburgh 21: 219-227.

Cribb, P.J. (1997). Slipper orchids of Borneo. Kota Kinabalu: Natural History Publications.

Dang, V.S., Toyama, H., Tagane, S., Hoang, N.S. \& Naiki, A. (2019). Calophyllum honbaense (Clusiaceae), a new species from Hon Ba Nature Reserve, southern Vietnam. Taiwania 64: 86-89.

Darbyshire, I. et al. [20 authors] (2017). Important Plant Areas: revised selection criteria for a global approach to plant conservation. Biodiversity and Conservation 26: 1767-1800.

Davison, G.W.H. (2019). Plant conservation in Singapore I: Historical and legal background. In: Middleton, D.J., Leong-Škorničková, J. \& Lindsay, S. (ed.) Flora of Singapore 1: 71-81.

Davison, G.W.H., Ng, P.K.L. \& Ho, H.C. (2008). The Singapore Red Data book: Threatened plants and animals of Singapore, 2nd ed., pp. 213-245. Singapore: Nature Society (Singapore) 
De Bruyn, M., Stelbrink, B., Morley, R.J., Hall, R., Carvalho, G.R., Cannon, C.H., van den Bergh, G., Meijaard, E., Metcalfe, I., Boitani, L., Maiorano, L. et al. (2014). Borneo and Indochina are Major Evolutionary Hotspots for Southeast Asian Biodiversity. Syst. Biol. 63(6): 879-901.

De Voogd, C.N.A. (1937a). Bali Zooals de Tourist het Niet Ziet. De Tropische Natuur 26: 1-9, $37-40$.

De Voogd, C.N.A. (1937b). Een Tocht naar Noesa Penida. De Tropische Natuur 26: 161-165.

De Voogd, C.N.A. (1940). De Batoer op Bali. De Tropische Natuur 29: 37-53.

De Wilde, W.J.J.O. (2014). Myristicaceae. Flora Malesiana, ser. I, vol. 14. Advanced Books: e1141.

De Wit, H.C.D. (1949). Short History of the Phytography of Malaysian Vascular Plants. Flora Malesiana, ser. I, vol. 4: lxxi-clxi.

Dickason, F.G. (1946). The Ferns of Burma. Ohio J. Sci. 46: 109-141.

Dransfield, J. (1984). The rattans of Sabah. Sabah Forest Records 13. Sandakan: Forest Department Sabah.

Dransfield, J. (1992). The rattans of Sarawak. Royal Botanic Gardens, Kew \& Sarawak Forest Department, Kuching.

Dransfield, S. (1992). The bamboos of Sabah. Sabah Forest Records 14. Royal Botanic Gardens, Kew \& Forestry Department Sabah, Sandakan.

Durant, C.L. (1933a). A tour in Brunei. Malayan Forester 2: 8-13.

Durant, C.L. (1933b). Report on the Forests of Brunei. Singapore: Government Printing Office.

FAO (2018). Papua New Guinea Multipurpose National Forest Inventory http://www.fao.org/ in-action/png-multipurpose-national-forest-inventory/en/. Accessed 1 Apr. 2019.

Fernando, E.S., Arbolonio, R.B. \& Lillo, E.P. (2017). Forest Flora of Dinagat Island: An Introductory Guide. Department of Environment and Natural Resources (DENR), Philippines.

Flora Malesiana Working Group (eds) (2011 onwards). Flora Malesiana Data Portal. Electronic resource. $<$ http://dev.e-taxonomy.eu/dataportal/flora-malesiana/>. Accessed 1 Apr. 2019.

Frodin, D. (2001). Guide to standard floras of the world, pp 824-826. Cambridge: Cambridge University Press.

Fujikawa, K., Kuroiwa, N., Maeda, A., Gale S., Shein Gay Ngai \& Aung Din (2008). 100 Wild Flowers of Natma Taung. Kochi: The Kochi Prefectural Makino Botanical Garden.

Fujikawa, K., Srisanga, P., Watthana, S., Ling Shein Mane, Law Shine, Tin Mya Soe \& Sheing Gay Ngai (2015). A guide to the forests of Natma Taung National Park, Myanmar plants of Natma Taung National Park, Myanmar. Kochi: The Kochi Prefectural Makino Botanical Garden.

Gagnepain, F. (1944). Flore générale de l'Indo-Chine, tome préliminaire. Paris: Masson et cie.

Gardner, S., Sidisunthorn, P. \& Anusarnunthorn, V. (2000). A field guide to the forest trees of northern Thailand. Bangkok: Kobfai Publishing.

Gardner, S., Sidisunthorn, P. \& Chayamarit, K. (2015). Forest trees of southern Thailand, vol. 1. Bangkok: Kobfai Publishing.

Gardner, S., Sidisunthorn, P. \& Chayamarit, K. (2016). Forest trees of southern Thailand, vol. 2. Bangkok: Kobfai Publishing.

Gardner, S., Sidisunthorn, P. \& Chayamarit, K. (2018). Forest trees of southern Thailand, vol. 3. Bangkok: Kobfai Publishing.

Geesink, R. (1990). The general progress of Flora Malesiana. In: Baas, P. et al. (eds) The plant diversity of Malesia, pp. 11-16. Dordrecht: Kluwer. 
Gibbs, L.S. (1917). A contribution to the phytogeography and flora of the Arfak Mountains. London: Taylor and Francis.

Gosliner, T.M. \& Burke M. (2013). From parachutes to partnerships: An integrated natural history museum expedition in the Philippines. Curator 56(1): 47-67.

Goss, A. (2011). The Floracrats State-sponsored Science and the Failure of the Enlightenment in Indonesia. Madison, Wisconsin: The University of Wisconsin Press.

Govaerts, R. (2001). How many species of seed plants are there? Taxon 50: 1085-1090.

Groombridge, B. (1992). Global Biodiversity: Status of the Earth's Living Resources. London: Chapman \& Hall.

Hamann, T., Müller, A., Ross, M.C., Sosef, M. \& Smets, E. (2014). Detailed mark-up of semimonographic legacy taxonomic works using FlorML. Taxon 63: 377-393.

Hasan bin Pukul \& Ashton, P.S. (1965, reprinted 1988). A Checklist of Brunei Trees. Government Printer, Brunei.

Henderson, A \& Peters, C.M. (2018). Rattans of Myanmar. WCS/MONREC, p. 116. https://myanmar.wcs.org/DesktopModules/Bring2mind/DMX/Download. aspx? EntryId=34276\&PortalId=126\&DownloadMethod=attachment. Accessed 15 April 2019.

Hendrian \& Middleton, D.J. (1999). A revision of Rauvolfia L. in Malesia. Blumea 44: 449470.

Henty, E.E. (1969). A Manual of Grasses of New Guinea. Botany Bulletin 1: 1-215.

Henty, E.E. (1981). Handbooks of the Flora of Papua New Guinea, vol. 2. Melbourne University Press, Carlton.

Heyne, K. (1927). De Nuttige Planten van Nederlands-Indie. s'Gravenhage (Hague): Van Hoeve.

Heyne, K. (1950). De Nuttige Planten van Indonesie. s'Gravenhage (Hague): Van Hoeve.

Heyne, K. (1987). Tumbuhan Berguna Indonesia (The Indonesian version of De Nuttige Planten van Indonesie, translated by the Forestry Research and Development Agency). Jakarta: Yayasan Sarana Wana Jaya.

Hidayat, S., Puspitaningtyas, D. M., Hartini, S., Munawaroh, E., Astuti, I. P., \& Wawangningrum, H. (2017). Eksplorasi Flora: 25 Tahun Menjelajah Rimba Nusantar (Flora Exploration: 25 Years Exploring Indonesian Forests). Centre for Plant Conservation Bogor Botanic Gardens - LIPI. Jakarta: LIPI Press.

Hilliard, O.M. (2004). A revision of Chirita sect. Liebigia (Gesneriaceae). Edinburgh J. Bot. 60: $361-387$

Hilliard, O.M. \& Burtt, B.L. (2002). The genus Agalmyla (Gesneriaceae-Cyrtandroideae). Edinburgh J. Bot. 59: 1-210.

Hooker, J.D. (1872-1897). The Flora of British India, vols 1-7. London: L. Reeve.

Hovenkamp, P. \& Cicuzza, D. (2013). Ferns of Sulawesi. Electronic resource. http:// sulawesiferns.myspecies.info/. Accessed 27.09.2018.

Hundley, H.G. (1987). List of Trees, Shrubs, Herbs and Principal Climbers, etc., Recorded from Burma with Vernacular Names, $4^{\text {th }}$ ed. Rangoon: Burma Forestry Department.

Hundley, H.G. \& U Chit Ko Ko (1961). List of Trees, Shrubs, Herbs and Principal Climbers, etc., Recorded from Burma with Vernacular Names, $3^{\text {rd }}$ ed. Rangoon: Superintendent, Government Printing and Stationary.

Inthakoun, L. \& Delang, C. (2008). Lao flora: a checklist of plants found in Lao PDR with scientific and vernacular names. Morrisville, NC, USA: Lulu Press.

Irawati \& Widyatmoko, D. (2019). Biodiversity in Indonesia. In: T. Pullaiah (ed.) Global Biodiversity, Volume 1, Selected Countries in Asia. Oakville: Apple Academic Press. 
Jacobs, M. (1962). Reliquiae Kerrianae. Blumea 11: 427-493.

Jin H.-Y., Ahn, T.-H., Lee, H.-J., Song, J.H., Lee, C.H., Kim, Y.J., Yoon, J.W. \& Chamg, K.S. (2016). A checklist of plants in Lao PDR. Pocheon-si: Korea National Arboretum of the Korea Forest Service.

Joffre, A.A., Muhd-Ariffin, A.K., Low, Y.W. \& Wong, K.M. (2015). Novitates Bruneienses, 1. A background to the botanical survey of Brunei Darussalam, and a new species of Jarandersonia (Malvaceae). Gard. Bull. Singapore 67: 51-60.

Johns, R.J. (1995). Malesia - An Introduction. Curtis's Bot. Mag. 12: 52-62.

Johns, R.J., Edwards, P.J., Utteridge, T.M.A. \& Hopkins, H.F. (2006). A Guide to the Alpine and Subalpine Flora of Mount Jaya. Kew: Royal Botanic Gardens, Kew.

Joppa, L.N., Roberts, D.L., Myers, N. \& Pimm, S.L. (2011). Biodiversity hotspots house most undiscovered plant species. Proc. Nat. Acad. Sci. U.S.A. 108: 13171-13176.

Kang, D.-H., Ling Shein Man, Kim, Y.-D. \& Ong, H.G. (2017a). New records of flowering plants of the flora of Myanmar collected from Natma Taung National Park (Chin State). Korean J. Pl. Taxon. 47(3): 199-206.

Kang, D.-H., Lee, J.-H.., Ong, H.-G., Ling, S.M. \& Kim, Y.D. (2017b). Seed plants of Natma Taung National Park, Myanmar. Incheon: National Institute of Biological Resouces (NIBR).

Kang, D.-H., Kyaw, N.O., Jung, E.-K., Shin, J.-S., Kim, Y.-D. \& Ong, H.G. (2018). New records of flowering plants for the flora of Myanmar collected from southern Shan State. Korean J. Pl. Taxon. 48(3): 218-229

Kelly, D. \& Sork, V.L. (2008). Mast seeding in perennial plants: why, how and where? Ann. Rev. Ecol. System. 33: 427-447.

Keng, H. (1978). Labiatae. Flora Malesiana, ser. I, vol. 8: 301-394.

Keng, H. (1990). The Concise Flora of Singapore. Volume II: Gymnosperms and Dicotyledons. Singapore: Singapore University Press.

Keng, H., Chin, S.C. \& Tan, H.T.W. (1998). The Concise Flora of Singapore. Volume II: Monocotyledons. Singapore: Singapore University Press.

Kerr, A.F.G. (1939). Early botanists in Thailand. J. Thailand Research Soc., Nat. Hist. Suppl. 12: $1-27$.

Khine, P.K., Fraser-Jenkins, C., Lindsay, S., Middleton, D.J., Miehe, G., Thomas, P., \& Kluge, J. (2017). A Contribution Toward the Knowledge of Ferns and Lycophytes from Northern and Northwestern Myanmar. Amer. Fern J. 107(4): 219-256.

Kiew, R. (1984). Towards a flora of Borneo. In: Sahid, I. et al. (eds) Research priorities in Malaysian biology, pp. 73-80. Bangi: Universiti Kebangsaan Malaysia.

Kiew, R. \& Rafidah, A.R. (2007). The flora of Peninsular Malaysia. Conservation Malaysia Bulletin 5: 1-4.

Kiew, R., Chung, R.C.K., Saw, L.G., Soepadmo, E. \& Boyce, P.C. (eds) (2010). Flora of Peninsular Malaysia, ser. II, vol. 1. Malayan Forest Records No 49. Kepong: Forest Research Institute Malaysia.

Kiew, R., Chung, R.C.K., Saw, L.G.; Soepadmo, E. \& Boyce P.C. (eds) (2011). Flora of Peninsular Malaysia, ser. II, vol. 2. Malayan Forest Records No. 49. Kepong: Forest Research Institute Malaysia.

Kiew, R., Chung, R.C.K., Saw, L.G. \& Soepadmo, E. (eds) (2012). Flora of Peninsular Malaysia, ser. II, vol. 3. Malayan Forest Records No 49. Kepong: Forest Research Institute Malaysia.

Kiew, R., Chung, R.C.K., Saw, L.G. \& Soepadmo, E. (eds) (2013). Flora of Peninsular Malaysia, ser. II, vol. 4. Malayan Forest Records No 49. Kepong: Forest Research Institute Malaysia. 
Kiew, R., Chung, R.C.K., Saw, L.G. \& Soepadmo, E. (eds) (2015). Flora of Peninsular Malaysia, ser. II, vol. 5. Malayan Forest Records No 49. Kepong: Forest Research Institute Malaysia.

Kiew, R., Chung, R.C.K., Saw, L.G. \& Soepadmo, E. (eds) (2017). Flora of Peninsular Malaysia, ser. II, vol. 6. Malayan Forest Records No. 49. Kepong: Forest Research Institute Malaysia.

Kiew, R., Chung, R.C.K., Saw, L.G. \& Soepadmo, E. (eds) (2018). Flora of Peninsular Malaysia, ser. II, vol. 7. Malayan Forest Records No. 49. Kepong: Forest Research Institute Malaysia.

Kim, Y.-D., Cho, S.-H., Sun, B.-Y., Hwang, I.-C. \& Moon, M.-O. (2012). Spermatophytes \& Pteridophytes. In: Lee W.-S. et al. (eds) Biodiversity of Cambodia-Cardamom Protected Forest \& Seima Biodiversity Conservation Area, pp. 96-277. Incheon: National Institute of Biological Resources.

Kochummen, K.M. (1989). Rhizophoraceae. In: Ng, F.S.P. (ed.) Tree Flora of Malaya, vol. 4: 302-323. Malayan Forest Records 26. Forest Department, West Malaysia.

KPPN/Bappenas (Kementerian Perencanaan Pembangunan Nasional/Badan Perencanaan Pembangunan Nasional/Indonesian Ministry of National Development Planning/ National Development Planning Board) (2016). Indonesian Biodiversity Strategy and Action Plan (IBSAP) 2015-2020. Jakarta.

Kress, W.J., DeFilipps, R.A, Farr, E. \& Daw Yin Yin Kyi (2003). A Checklist of the Trees, Shrubs, Herbs, and Climbers of Myanmar. Contr. U.S. Natl. Herb. 45: 1-590. Washington DC: National Museum of Natural History.

Kurten, E.L., Bunyavejchewin, S. \& Davies, S.J. (2017). Phenology of a dipterocarp forest with seasonal drought: Insights into the origin of general flowering. J. Ecol. 106: 126-136.

Kurz, S. (1877). Forest Flora of British Burma. Calcutta: Office of the Superintendent of Government Printing.

Kurzweil, H. \& Lwin, S. (2014). A guide to orchids of Myanmar. Kota Kinabalu: Natural History Publications (Borneo).

Lace, J.H. (1912). List of Trees, Shrubs and Principal Climbers, etc., Recorded from Burma with Vernacular Names. Calcutta: Government Publications.

Larsen, K. \& Larsen, S.S. (2006). Gingers of Thailand. Chiang Mai: Queen Sirikit Botanical Garden.

Le, K.K., Vo, V.C. \& Vu, V.C. (eds) (1969-1976). Common plants in Vietnam, vols 1-6. Hanoi: Publishing House for Science and Technology.

Le, T.C. (1999). Some basic characteristics of the Vietnamese flora. Hanoi: Publishing House for Science and Technology.

Leeuwenberg, A.J.M. (1985). Voacanga Thou. Series of revisions of Apocynaceae XV. Agric. Univ. Wageningen Pap. 85(3): 1-80.

Leeuwenberg, A.J.M. (1991). A revision of Tabernaemontana 1: The Old World species. London: Royal Botanic Garden Kew.

Leti, M., Hul, S., Fouché, J.-G., Cheng, S.K. \& David, B. (2013). Flore Photographique du Cambodge. Toulouse: Éditions Privat.

Li, P.T., Leeuwenberg, A.J.M. \& Middleton, D.J. (1995). Apocynaceae. Flora of China, vol. 16: $143-188$.

Lim, R.C.J., Leong-Škorničkova, J., Lindsay, S., Niissalo, M.A., Yam, T.W. \& Middleton, D.J. (2019). Plant conservation in Singapore II: practical implementation. In: Middleton, D.J., Leong-Škorničková, J. \& Lindsay, S. (ed.) Flora of Singapore 1: 83-106.

Lindsay, S. \& Middleton, D.J. (2012 onwards). Ferns of Thailand, Laos and Cambodia. http:// rbg-web2.rbge.org.uk/thaiferns/. Accessed 10 Nov. 2018. 
Lohman, D., De Bruyn, M., Page, T., Von Rintelen, K., Hall, R., Ng, P. L., Shih, H., Carvalho, G., \& Von Rintelen, T. (2011). Biogeography of the Indo-Australian Archipelago. Annual Rev. Ecol. Evol. Syst. 42 (1): 205-226.

Loureiro, J. de (1790). Flora Cochichinensis 2. Typis, Et Expensis Academicis, Ulyssipone.

Mangen, J.-M. (1993). Ecology and vegetation of Mt Trikora New Guinea (Irian Jaya/ Indonesia). Luxembourg: Ministere des Affaires Culturelles.

Masamune, G. (1942). Enumeratio Phanerogamarum Bornearum. Taihoku: Imperial University.

Masamune, G. (1945). Enumeratio Pteridophytarum Bornearum. Taihoku: Imperial University.

Mason, F. (1851). Flora Burmanica. Tavoy: Karen Mission Press.

McPherson, S. \& Amoroso, V.B. (2011). Field Guide to the Pitcher Plants of the Philippines. Poole: Redfern Natural History Productions.

Merrill, E.D. (1903). Botanical work in the Philippines, vol. 4. Manila: Bureau of Printing.

Merrill, E.D. (1912). A Flora of Manila. Bureau of Science Publ. No. 5. Manila: Bureau of Printing.

Merrill, E.D. (1918). Species Blancoanae. Bureau of Science Publ. No. 12. Manila: Bureau of Printing.

Merrill, E.D. (1921). A bibliographic enumeration of Bornean plants. J. Straits Branch Roy. Asiat. Soc., Special Number.

Merrill, E.D. (1923-1926). An Enumeration of Philippine Flowering Plants, vols 1-4. Manila: Bureau of Printing.

Merrill, E.D. (1926). An Enumeration of Philippine Flowering Plants, vol. 4. Bureau of Printing, Manila.

Merrill, E.D. (1941). The Upper Burma plants collected by Captain F. Kingdon Ward on the Vernay-Cutting Expedition, 1938-39. Brittonia 4: 20-188.

Merrill, E.D. (1953). Autobiographical: Early years, the Philippines, California. Asa Gray Bull., n.s. 2: 337-370.

Middleton, D.J. (1993). A taxonomic revision of Willughbeia Roxb. (Apocynaceae). Blumea 38: $1-24$.

Middleton, D.J. (1994). A taxonomic revision of Ichnocarpus (Apocynaceae). Blumea 39: 73-94.

Middleton, D.J. (1995a). A revision of Papuechites (Apocynaceae). Blumea 40: 439-442.

Middleton, D.J. (1995b). Baharuia, a new genus of Apocynaceae from Malesia. Blumea 40: 443-447.

Middleton, D.J. (1996a). Ecua, a new genus of Apocynaceae from Malesia. Blumea 41: 33-35.

Middleton, D.J. (1996b). A revision of Anodendron Roxb. (Apocynaceae). Blumea 41: 37-68.

Middleton, D.J. (1996c). A revision of Aganonerion Pierre ex Spire, Parameria Benth. and Urceola Roxb. (Apocynaceae). Blumea 41: 69-122.

Middleton, D.J. (1997). A revision of Parsonsia R.Br. in Malesia. Blumea 42: 191-248.

Middleton, D.J. (1999). Apocynaceae. Flora of Thailand, vol. 7(1): 1-152.

Middleton, D.J. (2000). Revision of Alyxia (Apocynaceae). Part 1: Asia and Malesia. Blumea 45: $1-146$.

Middleton, D.J. (2003a). A revision of Dyera (Apocynaceae, Rauvolfioideae). Gard. Bull. Singapore 55: 209-217.

Middleton, D.J. (2003b). Progress on the Flora of Thailand. Telopea 10: 33-42.

Middleton, D.J. (2004). A revision of Kopsia Blume (Apocynaceae: Rauvolfioideae). Harvard Pap. Bot. 9: 91-144.

Middleton, D.J. (2005a). A revision of Epigynum (Apocynaceae: Apocynoideae). Harvard Pap. Bot. 10: 67-81. 
Middleton, D.J. (2005b). A revision of Wrightia (Apocynaceae: Apocynoideae) in Malesia. Harvard Pap. Bot. 10: 161-182.

Middleton, D.J. (2007). A revision of Aeschynanthus (Gesneriaceae) in Thailand. Edinburgh J. Bot. 64: 363-429.

Middleton, D.J. (2009a). A revision of Aeschynanthus (Gesneriaceae) in Cambodia, Laos and Vietnam. Edinburgh J. Bot. 66: 391-446.

Middleton, D.J. (2009b). An update on the Apocynaceae in Thailand. Thai Forest Bull., Bot. (special issue): 143-155.

Middleton, D.J. (2010). Three new species of Wrightia (Apocynaceae: Apocynoideae) from Thailand. Gard. Bull. Singapore 61: 129-138.

Middleton, D.J. (2013). Wrightia calcicola (Apocynaceae: Apocynoideae), a new species from Thailand. Thai For. Bull. (Bot.) 41: 81-84.

Middleton, D.J. (2014). Apocynaceae, subfamilies Rauvolfioideae and Apocynoideae. Flora of Cambodia, Laos and Vietnam 33: 1-276.

Middleton, D.J. (2016). A revision of Aeschynanthus (Gesneriaceae) in Singapore and Peninsular Malaysia. Gard. Bull. Singapore 68: 1-63.

Middleton, D.J. (2019). Introduction. In: Middleton, D.J., Leong-Škorničková, J. \& Lindsay, S. (ed.) Flora of Singapore 1: 1-4.

Middleton, D.J. \& Turner, I.M. (2019). History of taxonomic research in Singapore. In: Middleton, D.J., Leong-Škorničková, J. \& Lindsay, S. (ed.) Flora of Singapore 1: 15-36.

Middleton, D.J., Atkins, H.J., Luu, H.T., Nishii, K. \& Möller, M. (2014). Billolivia, a new genus of Gesneriaceae from Vietnam with five new species. Phytotaxa 161: 241-269.

Middleton, D.J., Nishii, K., Puglisi, C., Forrest, L.L. \& Möller, M. (2015). Chayamaritia (Gesneriaceae: Didymocarpoideae), a new genus from Southeast Asia. Pl. Syst. Evol. 301: 1947-1966.

Middleton, D.J., Leong-Škorničková, J. \& Lindsay, S. (2019a). Flora of Singapore vol. 1. Singapore: National Parks Board.

Middleton, D.J., Leong-Škorničková, J. \& Lindsay, S. (2019b). Flora of Singapore vol. 7. Singapore: National Parks Board.

Middleton, D.J., Leong-Škorničková, J. \& Lindsay, S. (2019c). Flora of Singapore vol. 13. Singapore: National Parks Board.

Mitsuyuki, C., Tagane, S., Ngoc, N.V., Binh, H.T., Suddee, S., Ruangruea, S., Toyama, H., Mase, K., Yang, C.-J. Naiki, A. \& Yahara, T. (2017). Two new species of Neolitsea (Lauraceae), $N$. kraduengensis from Thailand and $N$. vuquangensis from Vietnam and an analysis of their phylogenetic positions using ITS sequences. Acta Phytotax. Geobot. 69(3): 161-173.

Monk, K. A., Fretes, Y. de., \& Reksodiharjo-Lilley, G. (1997). The Ecology of Nusa Tenggara and Maluku. Hong Kong: Periplus Editions Ltd.

Nagahama, A. et al. [19 authors] (2019). A Picture Guide for the Flora of Bidoup-Nui Ba National Park I: Mt. Langbian. Kyushu: Center for Asian Conservation Ecology, Kyushu University.

Nath, D.M. (1960). Botanical Survey of the Southern Shan States. Rangoon: University of Rangoon.

Newman, M.F. (2018). A checklist of the vascular plants of Lao PDR. http://padme.rbge.org. uk/laos/. Accessed 15.04.2019.

Newman, M.F., Burgess, P.F. \& Whitmore, T.C. (1996). Manuals of Dipterocarps for Foresters: Philippines. Edinburgh: Royal Botanic Garden Edinburgh.

Newman, M.F., Ketphanh, S., Svengsuksa, B., Thomas, P., Sengdala, K., Lamxay, V. \& Armstrong, K. (2007). A checklist of the vascular plants of Lao PDR. Edinburgh: Royal Botanic Garden Edinburgh. 
Newman, M.F., Chayamarit, K. \& Balslev, H. (2017). North-South Collaboration in Writing Tropical Floras: The Flora of Thailand at a crossroads. Scientia Danica, ser. B, Biologica 6: $177-186$

Ng, F.S.P. (ed.) (1978). Tree Flora of Malaya, vol. 3. Malayan Forest Records 26. Forest Department, West Malaysia.

Ng, F.S.P. (ed.) (1989). Tree Flora of Malaya, vol. 4. Malayan Forest Records 26. Forest Department, West Malaysia.

Ngoc, N.V., Hung, N.V., Binh, H.T., Tagane, S., Toyama, H., Son, H.T., Ha, T.V. \& Yahara, T. (2018). Lithocarpus vuquangensis (Fagaceae), a new species from Vu Quang National Park, Vietnam. PhytoKeys 95: 15-25.

Nguyen, D.T.L. \& Thomas, P. (2004). Conifers in Vietnam, an illustrated field guide. Hanoi: World Publishing House. (In Vietnamese)

Nguyen, H.N. (2005). Dipterocarps of Vietnam. Hanoi: Agriculture Publishing House.

Nguyen, T.B., Tran, D.D. \& Phan, K.L. (1984). Florae Taynguyenensis Enumeratio. Hanoi: Institute of Biology, Vietnam Academy of Science.

Nguyen, T.B. (ed.), Tran, T.P.A, Le, K.B., Nguyen, Q.B., Ha, T.D., Nguyen, V.D., Tran, D.D., Nguyen, K.D., Nguyen, T.D., Nguyen, H.H., Nguyen, T.H. et al. (2003). Checklist of Plant Species of Vietnam, vol. 2. Hanoi: Agriculture Publishing House.

Nguyen, T.B. (ed.), Tran, P.A, Tran, T.B., Le, K.B., Nguyen, Q.B., Nguyen, V.D., Nguyen, T.D., Vu, V.H., Duong, D.H., Tran, C.K. et al. (2005). Checklist of Plant Species of Vietnam, vol. 3. Hanoi: Agriculture Publishing House.

Nguyen, T.T. (2001). The orchids of Viet Nam, part 1. Ho Chi Minh City: Agriculture Publishing House.

Nic Lughadha, E., Govaerts, R., Belyaeva, I., Black, N., Lindon, H., Allkin, R., Magill, R.E. \& Nicolson, N. (2016). Counting counts: revised estimates of numbers of accepted species of flowering plants, seed plants, vascular plants and land plants with a review of other recent estimates. Phytotaxa 272: 82-88.

Niissalo, M.A., Wijedasa, L.S, Boyce, P.C. \& Leong-Škorničková, J. (2014). Hanguana neglecta (Hanguanaceae): a new plant species from a heavily collected and visited reserve in Singapore. Phytotaxa 188: 14-20.

Nor-Ezzawanis, A.T. (2018). Anisophylleaceae. In: Kiew, R., Chung, R.C.K., Saw, L.G. \& Soepadmo, E. (eds) Flora of Peninsular Malaysia, ser. II, vol. 7. Malayan Forest Records No. 49. Kepong: Forest Research Institute Malaysia.

Ong, P.T., O'Byrne, P., Saw, L.G. \& Chung, R.C.K. (2017). Checklist of Orchids of Peninsular Malaysia. Research Pamphlet No. 136. Kepong: Forest Research Institute Malaysia.

Pancho, J.V. (1983). Vascular Flora of Mt Makiling and Vicinity (Luzon: Philippines), Part 1. Kalikasan, Suppl. 1.

Pancho, J.V. \& Gruezo, W.S. (2006). Vascular Flora of Mt Makiling and Vicinity (Luzon: Philippines), Part 2. Los Baños: National Academy of Sciences and Technology, Philippines and Institute of Biological Sciences, University of the Philippines of the Philippines.

Parnell, J.A.N. (2000). The conservation of biodiversity: Aspects of Ireland's role in the study of tropical plant diversity with particular reference to the study of the Flora of Thailand and Syzygium. In: Rushton, B.S. (ed.) Biodiversity: The Irish dimension. Dublin: Royal Irish Academy.

Parnell, A.N., Simpson, D.A., Moat, J., Kirkup, D.W., Chantaranothai, P., Boyce, P.C., Bygrave, P., Dransfield, S., Jebb, M. H. P., Macklin, J. et al. (2003). Plant collecting spread and densities: their potential impact on biogeographical studies in Thailand. J. Biogeogr. 30: 193-209. 
Parris, B.S., Beaman, R.S. \& Beaman, J.H. (1992). The Plants of Mount Kinabalu 2. Ferns. Kew: Royal Botanic Gardens.

Parris, B.S., Kiew, R., Chung, R.C.K., Saw, L.G. \& Soepadmo, E. (eds) (2010). Flora of Peninsular Malaysia, ser. I, vol. 1. Malayan Forest Records No 48. Kepong: Forest Research Institute Malaysia.

Parris, B.S., Kiew, R., Chung, R.C.K. \& Saw, L.G. (eds) (2013). Flora of Peninsular Malaysia, ser. I, vol. 2. Malayan Forest Records No 48. Kepong: Forest Research Institute Malaysia.

Pelser, P.B., Barcelona, J.F. \& Nickrent, D.L. (eds) (2011 onwards). Co's Digital Flora of the Philippines. http://www.philippineplants.org. Accessed 28 Mar. 2019.

Penev, L. (2014). Classical monographs re-published in advanced open access. http://www. eurekalert.org/pub_releases/2014-06/pp-cmr061014.php. Accessed 08 Apr. 2019.

Pham-Hoang, H. (1970). Plants of South Vietnam, vol. 1. Saigon: Center for Study Materials, Ministry of Culture, Education and Youth.

Pham-Hoang, H. (1972). Plants of South Vietnam, vol. 2. Saigon: Center for Study Materials, Ministry of Culture, Education and Youth.

Pham-Hoang, H. (1991-1993). An Illustrated Flora of Vietnam, vols 1-3. Mekong Printing.

Pham-Hoang, H. (1999-2000). An Illustrated Flora of Vietnam, ed. 2, vols 1-3. Tre Publishing House.

Pham-Hoang, H. \& Nguyen, V.D. (1960). Plants of South Vietnam. Saigon: Center for Study Materials, Ministry of Culture, Education and Youth.

Phan, K.L. (1970). Preliminary checklist of plants in northern Vietnam. J. Forestry 9: 18-23. (In Vietnamese)

Phan, K.L. (2010). The Updated Checklist of the Fern Flora of Vietnam following the classification scheme of A. Smith et al. (2006). J. Fairylake Bot. Gard. 9(3): 1-13.

Phan, K.L., Pham, VT., Nguyen, S.K., Nguyen, T.T.H. \& Averyanov, L.V. (2013). Native Conifers of Vietnam - Updated checklist. J. Ecol. Econ. 45: 33-50. [In Vietnamese]

Phan, K.L., Pham, VT., Phan, K.L., Regalado, J., Averyanov, L.V. \& Maslin, B. (2017). Native Conifers of Vietnam - A review. Pakistan J. Bot. 49(5): 2037-2068.

Phengkhlai, C. \& Niyomdham, C. (1991). Flora in peat swamp areas of Narathiwat. Bangkok: Sombun Press.

Pierre, L. (1880-1907). Flore forestière de la Cochinchine. Paris: O. Doin

Pócs, T. (1965). Analyse aire-géographique et ecologique de la flore du Vietnam Nord. Az Egri Tanárképzö Föiskola Tudományos Közleményei 3: 395-452.

Podzorski, A.C. (1985). The Palawan Botanical Expedition 1984. Fl. Males. Bull. 38: 179-182.

Pooma, R. (ed.) (2005). A preliminary checklist of threatened plants in Thailand. Bangkok: Forest Herbarium, National Park, Wildlife and Plant Conservation Department.

Pottinger, E. \& Prain, D. (1898). A note on the botany of the Kachin Hills NE of Myitkyina. Rec. Bot. Surv. India 11(1): 215-310.

Poulsen, A.D. (2006). Etlingera of Borneo. Kota Kinabalu: Natural History Publications (Borneo) in association with Royal Botanic Garden Edinburgh.

Prance, G.T. (2001). Discovering the plant world. Taxon 50: 345-359.

Prance, G.T., Beentje, H., Dransfield, J. \& Johns, R. (2000). The tropical flora remains undercollected. Ann. Missouri Bot. Gard. 87: 67-71.

Primavera, J.H. \& Sadaba, R.B. (2012). Beach Forest Species and Mangrove Associates in the Philippines. Iloilo: Southeast Asian Fisheries Development Center.

Primavera, J.H., Sadaba, R.B. Lebata, M.J.H.L. \& Altamirano, J.P. (2004). Handbook of Mangroves in the Philippines - Panay. Iloilo: Southeast Asian Fisheries Development Center. 
Puff, C., Chayamarit, K. \& Chamchumroon, V. (2005). Rubiaceae of Thailand: A Pictorial Guide to Indigenous and Cultivated Genera. Bangkok: Forest Herbarium, National Park Wildlife and Conservation Service.

Puglisi, C. \& Middleton, D.J. (2017a). A revision of Microchirita (Gesneriaceae) in Thailand. Gard. Bull. Singapore 69: 211-284.

Puglisi, C. \& Middleton, D.J. (2017b). A revision of Boea (Gesneriaceae). Edinburgh J. Bot. 75: 19-49.

Puglisi, C. \& Middleton, D.J. (2017c). A revision of Damrongia (Gesneriaceae) in Thailand. Thai For. Bull. (Bot.) 45: 79-93.

Puglisi, C. \& Middleton, D.J. (2017d). A revision of Dorcoceras (Gesneriaceae) in Thailand. Thai For. Bull. (Bot.) 45: 10-17.

Regalado, Jr., J.C., Nguyen, T.H., Phan K.L., Averyanov, L. \& Harder, D.K. (2005). New insights into the diversity of the Flora of Vietnam. Biol. Skr. 55: 189-197.

Rensch, B. (1930). Eine biologische Reise nach den Kleinen Sunda-Inseln. Berlin: Gebruder Borntraeger.

Ricklefs, M.C. (1993). A History of Modern Indonesia Since c. 1300, $2^{\text {nd }}$ ed. Stanford: Stanford University Press.

Ridley, H.N. (1900). The Flora of Singapore. J. Straits Branch Roy. Asiat. Soc. 33: 27-196.

Ridley, H.N. (1920). On a collection of plants from peninsular Siam. J. Fed. Malay States Mus. 10: $65-156$.

Ridley, H.N. (1922-1925). Flora of the Malay Peninsula, vols. 1-5. London: Lovell Reeve.

Risna, R.A., Kusuma, W.C.K., Widyatmoko, D., Hendrian, R., \& Pribadi, D.O. (2010). Spesies Prioritas untuk Konservasi Tumbuhan Indonesia (Priority Species for Conserving Indonesian Plants). Centre for Plant Conservation Bogor Botanic Gardens - LIPI. Jakarta: LIPI Press.

Rojo, J.P. \& Aragones, E.G. Jr. (1997). Botanical Identification Handbook on Philippine Dipterocarps. Los Baños: Forest Products Research and Development Institute, Department of Science and Technology.

Rodger, A. (1922). List of Trees, Shrubs, and Principal Climbers, etc., Recorded from Burma with Vernacular Names, $2^{\text {nd }}$ ed. Rangoon: Superintendent, Government Printing and Stationary.

Roos, M. (1997). Flora Malesiana: progress, needs and prospects. In: Dransfield, J., Coode, M.J.E. \& Simpson, D.A. (eds) Plant Diversity in Malesia III: Proceedings of the Third International Flora Malesiana Symposium 1995, pp. 231-246. London: Royal Botanic Gardens Kew.

Roos, M. (2003). Flora Malesiana 1991-2001: What has been achieved: revitalisation, momentum? What next? Telopea 10(1): 1-10.

Rudjiman (1987). A revision of Beaumontia Wallich, Kibatalia G. Don and Vallariopsis Woodson (Apocynaceae), series of revisions of Apocynaceae XIX. Agric. Univ. Wageningen Pap. 86: 1-99.

Rundel, P.W. \& Middleton, D.J. (2017). The flora of the Bokor Plateau, southeastern Cambodia: a homage to Pauline Dy Phon. Cambodian J. Nat. Hist. 2017(1): 17-37

Sakai, S. (2002). General flowering in lowland mixed dipterocarp forests of South-east Asia. Biol. J. Linn. Soc. 75: 233-247.

Santisuk, T., Smitinand, T., Hoamuangkaew, W., Ashton, P.S., Sohmer, S.H. \& Vincent, J.R. (1991). Plants for Our Future: Botanical Research and Conservation Needs in Thailand. Research Publication by USAID/RFD/WWF-US. Printed in Bangkok. 
Saw, L.G. \& Chung, R.C.K. (2007). Towards the flora of Malaysia. In: Chua, L.S.L.; Kirton, L.G. \& Saw, L.G. (eds) Proceedings of seminar and workshop on the status of biological diversity in Malaysia \& threat assessment of plant species in Malaysia. Kepong: Forest Research Institute Malaysia.

Saw, L.G. \& Chung, R.C.K. (2015). The Flora of Malaysia projects. Rodriguésia 66(4): 947960.

Severin, T. (1997). The Spice Island Voyage: In Search of Wallace. Great Britain: Abacus Travel.

Sidiyasa, K. (1998). Taxonomy, phylogeny, and wood anatomy of Alstonia (Apocynaceae). Blumea, Suppl. 11: 1-230.

Smitinand, T. (2014). Thai plant names, revised edition. Bangkok: Forest Herbarium, National Park, Wildlife and Plant Conservation Department.

Smythies, B.E. (1956). Forests and forestry in Brunei. Malayan Forester 19: 19-24.

Smythies, B.E. (1965). Common Sarawak trees. Sarawak: Borneo Literature Bureau.

Soejarto, D.D. (1989). Plant collecting in Palawan. Bull. Field Mus. Nat. Hist. 60(5): 24-28.

Soejarto, D.D., Gyllenhaal, C., Ashton, P.S. \& Sohmer, S.H. (1996). Plant explorations in Asia under the sponsorship of the National Cancer Institute 1986-1991: An overview. In: Balick, M.J., E. Elisabetsky, \& S.A. Laird (eds) Medicinal Plant Resources of the Tropical Forest, pp. 284-310. New York: Columbia University Press.

Soepadmo, E. \& Saw, L.G. (eds) (2000). Tree flora of Sabah and Sarawak, vol. 3. Forest Research Institute Malaysia, Kuala Lumpur, Sabah Forestry Department, Sandakan \& Sarawak Forestry Department, Kuching.

Soepadmo, E. \& Wong, K.M. (eds) (1995). Tree flora of Sabah and Sarawak, vol. 1. Forest Research Institute Malaysia, Kuala Lumpur, Sabah Forestry Department, Sandakan \& Sarawak Forestry Department, Kuching.

Soepadmo, E., Wong, K.M. \& Saw, L.G. (eds) (1996). Tree flora of Sabah and Sarawak, vol. 2. Forest Research Institute Malaysia, Kuala Lumpur, Sabah Forestry Department, Sandakan \& Sarawak Forestry Department, Kuching.

Soepadmo, E., Saw, L.G. \& Chung, R.C.K. (eds) (2002). Tree Flora of Sabah and Sarawak, vol. 4. Forest Research Institute Malaysia, Kuala Lumpur, Sabah Forestry Department, Sandakan \& Sarawak Forestry Department, Kuching.

Soepadmo, E., Saw, L.G. \& Chung, R.C.K. (eds) (2004). Tree Flora of Sabah and Sarawak, vol. 5. Forest Research Institute Malaysia, Kuala Lumpur, Sabah Forestry Department, Sandakan \& Sarawak Forestry Department, Kuching.

Soepadmo, E., Saw, L.G. \& Chung, R.C.K. (eds) (2007). Tree Flora of Sabah and Sarawak, vol. 6. Forest Research Institute Malaysia, Kepong.

Soepadmo, E., Saw, L.G., Chung, R.C.K. \& Kiew, R. (eds) (2011). Tree Flora of Sabah and Sarawak, vol. 7. Forest Research Institute Malaysia, Kepong.

Soepadmo, E., Saw, L.G., Chung, R.C.K. \& Kiew, R. (eds) (2014). Tree Flora of Sabah and Sarawak, vol. 8. Forest Research Institute Malaysia, Kepong.

Sohmer, S.H. (1996). The urgency of documenting plant diversity: the Flora of the Philippines Project - a last chance to study the plant diversity of the Philippines. In: Stuessy, T.F. \& S.H. Sohmer (eds) Sampling the Green World, pp. 28-40. New York: Columbia University Press.

Sork, V.L. (1993). Evolutionary ecology of mast-seeding in temperate and tropical oaks (Quercus spp.). Vegetatio 107/108: 133-147. 
Souladeth P., Tagane S., Zhang M., Okabe N. \& Yahara T. (2017). Flora of Nam Kading National Protected Areas I: a new species of yellow flowered Strobilanthes (Acanthaceae), $S$. namkadingensis. PhytoKeys 81: 11-17.

Souladeth, P., Tagane, S. \& Yahara, T. (2019). Flora of Nam Kading National Protected Area V: Two new species of Camellia (Theaceae), C. namkadingensis and C. roseacea. Thai For. Bull. (Bot.) 47: 84-90.

Souvannakhoummae K., Souladeth P., Tagane S., Yang C.-J. \& Yahara T. (2019). Flora of Nam Kading National Protected Area VI: Didymocarpus middletonii (Gesneriaceae), a new species from limestone. Edinburgh J. Bot. 76: 45-54.

Stone, B.C. (1991). Expeditions and other field work - Philippines. Fl. Males. Bull. 10: 314315.

Sukarya, D.G. (ed.) (2013). The 3500 Plant Species of the Botanic Gardens of Indonesia. Jakarta: PT Sukarya \& Sukarya Pandetama.

Tagane, S., Toyama, H., Chhang, P., Nagamasu, H., \& Yahara, T. (2015a). Flora of Bokor National Park, Cambodia I: Thirteen new species and one change in status. Acta Phytotax. Geobot. 66(2): 95-135.

Tagane, S., Fuse, K., Toyama, H., Chhang, P. \& Yahara, T. (2015b). A Picture Guide of Forest Trees in Cambodia III: Kratie. Kyushu: Center for Asian Conservation Ecology, Kyushu University.

Tagane, S., Toyama, H., Fuse, K., Chhang, P., Naiki, A., Nagamasu, H. \& Yahara, T. (2017). A Picture Guide of Forest Trees in Cambodia IV: Bokor National Park. Kyushu: Center for Asian Conservation Ecology, Kyushu University.

Tagane, S., Souladeth, P., Zhang, M. \& Yahara, T. (2018a). Flora of Nam Kading National Protected Area IV: Two new species of Annonaceae, Monoon namkadingense and Neouvaria laosensis, Phytotaxa 336: 82-88.

Tagane, S., Souladeth, P., Rueangruea, S., Okabe, N., Zhang, M., Chayer, S., Yang C.-J. \& Yahara, T. (2018b). Flora of Nam Kading National Protected Area II: 30 new records of angiosperms for Laos. Edinburgh J. Bot. 75(1): 107-116.

Tan, B.C. \& Rojo, J.P. (1989). Floristic inventory of the Philippine tropical rain forests. In: Campbell, D.G. \& Hammond, D. (eds) Floristic Inventory of Tropical Countries, pp. 44-62. New York Botanical Garden, New York.

Tan, B.C. \& Shevock, J.R. (2014). Noteworthy mosses and a new variety collected from the 2014 joint expedition of CAS and CMUH new to Mindanao Island of the Philippines. Bryophyte Diversity Evol. 36(1): 22-30.

Tanaka, N., Koyama, T. \& Murata, J. (2006). The Flowering Plants of Mt. Popa, Central Myanmar; Results of Myanmar-Japanese Joint Expeditions 2000-2004. Makinoa, n.s. 5: $1-102$.

Thai, V.T. (1970). Forest Vegetation of Vietnam. Hanoi: Science and Technology Publishing House.

Thai, V.T. (1978). Forest Vegetation of Vietnam from an ecological perspective. Hanoi: Science and Technology Publishing House.

Thiers, B. [continuously updated]. Index Herbariorum: A global directory of public herbaria and associated staff. New York Botanical Garden's Virtual Herbarium. http://sweetgum. nybg.org/ih/ Accessed 04 Apr. 2019.

Thomas, D.C. \& Roos, M. (2016). Flora Malesiana: a new secretariat branch at Singapore Botanic Gardens. Taxon 65: 1219.

Thomas, D.C., Ardi, W.H., Girmansyah, D. \& Hughes, M. (2013). Sulawesi Begonia Data Portal. Electronic resource. http://dev.e-taxonomy.eu/dataportal/flora-malesianaprospective/. Accessed 27 Sep. 2018. 
Toyama, H., Tagane, S., Kajisa, T., Chhang, P., Ichihasi, R. \& Yahara, T. (2012). A Picture Guide of Forest Trees in Cambodia I: Kampong Chhnang. Kyushu: Center for Asian Conservation Ecology, Kyushu University.

Toyama, H., Tagane, S., Chhang, P., Kajisa, T., Ichihashi, R., Samret, V., Ma, V., Sokh, H., Katayama, A., Itadani, H. et al. (2013a). Inventory of the Woody Flora in Permanent Plots of Kampong Thom and Kampong Chhnang Provinces, Cambodia. Acta Phytotax. Geobot. 64: 45-105.

Toyama, H., Tagane, S., Kajisa, T., Chhang, P. \& Yahara, T. (2013b). A Picture Guide of Forest Trees in Cambodia II: Kampong Thom. Kyushu: Center for Asian Conservation Ecology, Kyushu University.

Turner, I.M. (1993). The names used for Singapore plants since 1900. Gard. Bull. Singapore 45: $1-287$.

Turner, I.M. (1997 ['1995’]). A catalogue of the vascular plants of Malaya. Gard. Bull. Singapore 47: 1-757.

Utteridge, T.M.A. \& de Kok, R. (2007). Where do we go from here - and how often? In: Hodkinson, T.R. \& J.A.N. Parnell (eds) Reconstructing the tree of life: taxonomy and systematics of species rich taxa, pp. 291-298. Systematics Association Special Volume 72. London: CRC Press.

Utteridge, T.M.A. \& Edwards, P.J. (2009). The subalpine and alpine flora of Mount Jaya (New Guinea): status and threats. Blumea 54: 280-283.

Van Balgooy, M.M.J. \& Widjaja, E. A. (2014). Flora of Bali: A Provisional Checklist. Reinwardtia 14(1): 219-221.

Van Royen, P. (1964). Manual of the forest trees of Papua New Guinea, parts 2-8. Division of Botany, Lae.

Van Royen, P. (1979a). The Alpine Flora of New Guinea, vol. 1. Cramer, Vaduz, 1-317.

Van Royen, P. (1979b). The Alpine Flora of New Guinea, vol. 2. Cramer, Vaduz, 1-1232.

Van Royen, P. (1982). The Alpine Flora of New Guinea, vol. 3. Cramer, Vaduz, 1233-2404.

Van Royen, P. (1983). The Alpine Flora of New Guinea, vol. 4. Cramer, Vaduz, 2405-3516.

Van Steenis, C.G.G.J. (1950). Malaysian Plant Collectors and Collections, being a Cyclopedia of Botanical Exploration in Malaysia and a Guide to the Concerned Literature up to the Year 1950. Flora Malesiana ser. I: 1-639.

Van Steenis, C.G.G.J. \& Van Steenis-Kruseman, M.J. (1953). A Brief Sketch of the Tjibodas Mountain Garden. Fl. Males. Bull. 10: 312-351.

Van Steenis-Kruseman, M.J. (1950). Malaysian plant collectors and collections. In: C.G.G.J. van Steenis (ed.) Flora Malesiana ser. I, vol. 1. Djakarta: Noordhoff-Kolff N.V.

Van Welzen, P.C. (continuously updated). Flora Malesiana Euphorbiaceae. Leiden: Naturalis Biodiversity Center. www.nationaalherbarium.nl/euphorbs. Accessed 04 Apr. 2019.

Van Welzen, P.C. \& Chayamarit, K. (2017). Flora of Thailand Euphorbiaceae. Naturalis Biodiversity Center, Leiden; Forest Herbarium, National Park, Wildlife and Plant Conservation Department, Bangkok. www.nationaalherbarium.nl/thaieuph. Accessed 09 Sep. 2018.

Van Welzen, P.C., Slik, J.W.F. \& Alahuhta, J. (2005). Plant distribution patterns and plate tectonics in Malesia. Biologiske Skrifter 55: 199-217.

Veldkamp, J.F. (1989). A note on Philippine collections of F.M. Blanco and A. Llanos. Fl. Males. Bull. 10(2): 143-145.

Verdcourt, B. (1979). A Manual of New Guinea Legumes. Lae: Division of Botany.

Vidal, J.E. (1959). Noms vernaculaires de plantes (Lao, Mèo, Kha) en usage au Laos. Bull. Ecol. Franc. Extreme-Orient 49(2): 435-608. 
Vidal, S. (1883). Sinopsis de familias y generos de plantas leñosas de Filipinas. Manila: Cofre.

Vidal, S. (1885). Phanerogamie Cumingianae Philippinarum. Manila: Cofre.

Vidal, S. (1886). Revision de las plantas vasculares Filipinas. Manila: M. Perez.

Vietnam Ministry of Forestry (1971-1988). Vietnam forest trees, vols 1-7. Hanoi: Agriculture Publishing House.

Vietnam National University, Ha Noi (2001). Checklist of Plant Species of Vietnam, vol. 1. Hanoi: Agriculture Publishing House.

Von Rintelen, K., Arida, E., \& Hauser, C. (2017). A Review of Biodiversity-Related Issues and Challenges in Megadiverse Indonesia and other Southeast Asian countries. Research Ideas and Outcomes 3: e20860.

Vu, V.D. (ed.) (1996). Vietnam Forest Trees. Hanoi: Agriculture Publishing House.

Wai, J.S., Thaitong, O., Sridith, K. \& Middleton, D.J. (2012 ['2011']). Willughbeia tenuiflora (Apocynaceae: Rauvolfioideae), a new record for Thailand. Thai Forest Bull., Bot. 39: 37-39.

Wallace, A.R. (1869). The Malay Archipelago: The Land of the Orang Utan and the Bird of Paradise. New York: Harper \& Brothers Publishers.

Watson, M.F. \& Smith, A. (2004). The Umbellifers of Myanmar: a last piece in the Asian puzzle. S. African J. Bot. 70(3): 427-432.

Weber, A. \& Burtt, B.L. (1998 ['1997']). Revision of the genus Ridleyandra (Gesneriaceae). Beitr. Biol. Pflanzen 70: 225-273.

Whitmore, T.C. (ed.) (1972). Tree flora of Malaya, vol. 1. Malayan Forest Records 26. Forest Department, West Malaysia.

Whitmore, T.C. (ed.) (1973). Tree flora of Malaya, vol. 2. Malayan Forest Records 26. Forest Department, West Malaysia.

Whitten, A.J., Mustafa, M. \& Henderson, G.S. (1987). The Ecology of Sulawesi. Yogyakarta: Gadjah Mada University Press.

Widjaja, E.A. \& Kartawinata, K. (2013). Economic Botany in Indonesia from the Herbarium Amboinense to the Plant Resources of Southeast Asia. Allertonia 13: 56-71.

Widyatmoko, D. (2018). Inovasi dan Strategi Konservasi Tumbuhan Indonesia untuk Mengurangi Laju Kepunahan (Conservation Strategy and Innovation of Indonesian Plants to Reduce the Extinction Rate). Orasi Pengukuhan Profesor Riset Bidang Konservasi dan Pengelolaan Lingkungan (Inaugural Speech of Research Professor in the Field of Conservation and Environmental Management). Indonesian Institute of Sciences (LIPI), 18 December 2018. Jakarta: LIPI Press.

Willis, K.J. (2017). State of the World's Plants. Report. Kew: Royal Botanic Gardens.

Womersley, J.S. (ed.) (1978). Handbooks of the Flora of Papua New Guinea, vol. 1. Melbourne University Press, Carlton.

Wong, K.M. (1988). The Constitution of a National Park in the Batu Apoi Forest Reserve of the Temburong District of Negara Brunei Darussalam: Background and Preliminary Considerations. Unpublished report. Forestry Department, Brunei Darussalam.

Wong, K.M. (1995). A brief history of botanical collecting and documentation in Borneo. In: Soepadmo, E. \& Wong, K.M. (eds) Tree flora of Sabah and Sarawak, vol. 1, pp. XXIXLI. Forest Research Institute Malaysia, Kuala Lumpur, Sabah Forestry Department, Sandakan \& Sarawak Forestry Department, Kuching.

Wong, K.M. (2015). Studies in Southeast Asian Melastoma (Melastomataceae), 1. Morphological variation in M. malabathricum and notes on rheophytic taxa and interspecific hybridisation in the genus. Gard. Bull. Singapore 67: 387-401. 
Wong, K.M. (2016). Studies in Southeast Asian Melastoma (Melastomataceae), 2. The genus Melastoma in Borneo, including 31 new species. Kota Kinabalu: Natural History Publications (Borneo) in association with National Parks Board Singapore.

Wong, K.M. (2017). Saurauia in Borneo. A revision with 62 new species. Kota Kinabalu: Natural History Publications (Borneo) in association with National Parks Board Singapore.

Wong, K.M. \& Kamariah, A.S. (eds) (1999). Trees and Forests of Brunei Darussalam. Bandar Sri Begawan: University of Brunei Darussalam, Forestry Department Brunei \& Brunei Shell Petroleum Co. Sdn. Bhd.

Wong, K.M., Joffre, A.A., Low, Y.W. \& Muhd-Ariffin, A.K. (2015). Rainforest Plants and Flowers of Brunei Darussalam. Brunei: Forestry Dept., Ministry of Industry \& Primary Resources.

Wood, J.J. \& Cribb, P.J. (1994). A checklist of orchids of Borneo. London: Royal Botanic Gardens Kew.

Wood, J.J., Beaman, R.S. \& Beaman, J.H. (1993). The plants of Mount Kinabalu 2. Orchids. London: Royal Botanic Gardens Kew.

Wood, J.R.I. \& Scotland, R.W. (2009). New and little-known species of Strobilanthes (Acanthaceae) from India and South East Asia. Kew Bull. 64: 3-47.

Xu, Z.R., Burtt, B.L., Skog, L.E. \& Middleton, D.J. (2008). A Revision of Paraboea (Gesneriaceae). Edinburgh J. Bot. 65: 161-347.

Yahara, T., Akasaka, M., Hirayama, H., Ichihashi, R., Tagane, S., Toyama, H., \& Tsujino, R. (2012). Strategies to observe and assess changes of terrestrial biodiversity in the AsiaPacific Regions. In: Nakano, S., Yahara, T. \& Nakashizuka, T. (eds) The Biodiversity Observation Network in the Asia-Pacific Region. Japan: Springer.

Yang C.-J., Tagane S., Souladeth P., Okabe N., Hu J.-M., Yahara T. (2018). Flora of Nam Kading National Protected Area III: Begonia namkadingensis (Begoniaceae), a new species in limestone area. Phytotaxa 334: 195-199.

Yao, T.L. (2015). Aristolochiaceae. In: Kiew, R., Chung, R.C.K., Saw, L.G. \& Soepadmo, E. (eds) Flora of Peninsular Malaysia, ser. II, vol. 5, pp. 5-46. Kepong: Forest Research Institute Malaysia.

Yee, A.T.K., Corlett, R.T., Liew, S.C. \& Tan, H.T.W. (2011). The vegetation of Singapore - an updated map. Gard. Bull. Singapore 63: 205-212.

Yee, A.T.K., Chong, K.Y., Seah, W.W., Lua, H.K. \& Yang, S. (2019). Vegetation of Singapore. In: Middleton, D.J., Leong-Škorničková, J. \& Lindsay, S. (ed.) Flora of Singapore 1: 47-70.

Zhang, M., Tagane, S., Toyama, H., Kajisa, T., Chhang, P., \& Yahara, T. (2016). Constant tree species richness along an elevational gradient of Mt. Bokor, a table-shaped mountain in southwestern Cambodia. Ecol. Res. 31: 495-504. 
